\title{
Health Benefits and Molecular Mechanisms of Resveratrol: A Narrative Review
}

\author{
Xiao Meng ${ }^{1}$, Jing Zhou ${ }^{2}$, Cai-Ning Zhao ${ }^{3}$, Ren-You Gan ${ }^{4, *(1)}$ and Hua-Bin $\mathrm{Li}^{1}{ }^{1}$ (1) \\ 1 Guangdong Provincial Key Laboratory of Food, Nutrition and Health, Department of Nutrition, \\ School of Public Health, Sun Yat-Sen University, Guangzhou 510080, China; \\ mengx7@mail2.sysu.edu.cn (X.M.); lihuabin@mail.sysu.edu.cn (H.-B.L.) \\ 2 School of Public Health, Hainan Medical University, Haikou 571199, China; hy0208035@hainmc.edu.cn \\ 3 Department of Clinical Oncology, Li Ka Shing Faculty of Medicine, The University of Hong Kong, \\ Hong Kong 999077, China; zhaocn@hku.hk \\ 4 Research Center for Plants and Human Health, Institute of Urban Agriculture, \\ Chinese Academy of Agricultural Sciences, Chengdu 610213, China \\ * Correspondence: ganrenyou@caas.cn; Tel.: +86-28-8020-3191
}

Received: 5 February 2020; Accepted: 12 March 2020; Published: 14 March 2020

check for updates

\begin{abstract}
Resveratrol is a bioactive compound in many foods. Since its anticancer activity was reported in 1997, its health benefits have been intensively investigated. Resveratrol has antioxidant, anti-inflammatory, immunomodulatory, glucose and lipid regulatory, neuroprotective, and cardiovascular protective effects, therefore, can protect against diverse chronic diseases, such as cardiovascular diseases (CVDs), cancer, liver diseases, obesity, diabetes, Alzheimer's disease, and Parkinson's disease. This review summarizes the main findings of resveratrol-related health benefits in recent epidemiological surveys, experimental studies, and clinical trials, highlighting its related molecular mechanisms. Resveratrol, therefore, has been regarded as a potent candidate for the development of nutraceuticals and pharmaceuticals to prevent and treat certain chronic diseases.
\end{abstract}

Keywords: resveratrol; bioactivities; anticancer; anti-obesity; antidiabetes; molecular mechanisms

\section{Introduction}

Many foodstuffs and their bioactive components are beneficial to certain diseases including cardiovascular diseases (CVDs) and cancer [1,2]. Resveratrol is a polyphenol, which naturally occurs in numerous foods, such as blueberries and peanuts, as well as grapes and their derived products like red wine [3]. Since resveratrol was reported to possess strong anticancer properties in tumor initiation, promotion, and progression stages in the well-regarded journal Science in 1997 [4], its bioactivities and health benefits have been intensively investigated. Many epidemiologic studies demonstrated that resveratrol is effective in the prevention of some diseases, such as CVDs and cancer [5,6]. Additionally, numerous experimental studies have illustrated that resveratrol is beneficial to a broad range of diseases, including CVDs, diabetes, obesity, cancer, liver diseases, Alzheimer's disease, and Parkinson's disease through redox/inflammatory/immune signaling pathways as well as the interplay between lipid and glucose metabolism [7-14]. Driven by the promising results from experimental research, many clinical trials have also elicited the efficacy of resveratrol against certain diseases $[15,16]$.

This review summarizes the main findings regarding the bioactivities and health impacts of resveratrol, based on systematically searching English literature from Web of Science Core Collection and PubMed in the last five years, using the key word "resveratrol". The literature was categorized into epidemiological surveys, experimental studies, and clinical trials. In particular, this review highlights the health benefits of resveratrol on chronic diseases including CVDs, cancer, liver diseases, obesity, 
diabetes, Alzheimer's disease, and Parkinson's disease, and its related molecular mechanisms. We hope that this narrative review paper can provide updated information about resveratrol and can attract more attention to its health benefits.

\section{Observational Studies}

Since resveratrol was illustrated to be one of the key factors in wine contributing towards the French paradox (high intake of saturated fat but low mortality from coronary heart disease), it has attracted overwhelming interest worldwide, and many epidemiological studies have investigated the relationship between resveratrol consumption and human health [17-20]. Specifically, dietary patterns rich in resveratrol were demonstrated to significantly reduce all-cause mortality [21,22]. Resveratrol also showed its potential to improve CVD risk factors, presenting significantly decreased fasting blood glucose, triglycerides (TGs), and heart rate [6]. In addition, a case-control study reported a significant inverse association between resveratrol from grapes (but not from wine) and breast cancer risk [17]. Furthermore, a lower risk of esophageal cancer was linked with higher resveratrol intake [5]. However, some null results or even harmful effects on health have also been reported. For instance, in a cross-sectional study in the Iranian population, resveratrol intake (top quantile, $0.054 \mathrm{mg}$ /day and more) was positively associated with high blood pressure (hazard ratios, HR: $1.52 ; 95 \%$ confidence intervals, $95 \%$ CI: 1.02-2.27), without an significant association with waist circumference, TG, high-density lipoprotein (HDL), blood glucose, and metabolic syndrome [19]. Similar null outcomes were found in other studies [18,23]. In fact, the findings from different epidemiological studies are often inconsistent, because their validity depends on many factors like the study design, sample size, resveratrol dose, follow-up duration, as well as the participants' race, health status, eating patterns, and their food preference (Table 1). Nevertheless, the positive results support further exploration of what other health effects resveratrol might provide and how it achieves them. 
Table 1. The results of resveratrol from observational studies.

\begin{tabular}{|c|c|c|c|c|c|}
\hline Population/Country & Study Name/Type & Sample Size (Valid Data) & Dose and Schedule & $\begin{array}{c}\text { Main Findings: } \\
\text { Resveratrol vs. Measurements/Risk Factors/Biomarkers }\end{array}$ & Ref. \\
\hline Swiss/Switzerland & Case-control & $\begin{array}{l}\mathrm{N}=971 \\
\text { (all female; case, 369; } \\
\text { control, 602) }\end{array}$ & $\begin{array}{l}\text { Tertiles: } \\
\text { T1: } 0.0-73.0 \mu \mathrm{g} / \text { day } \\
\text { T2: } 73.1-160.7 \mu \mathrm{g} / \mathrm{day} \\
\text { T3: >160.7 } \mu \mathrm{g} / \text { day (food-frequency } \\
\text { questionnaire, FFQ, on weekly } \\
\text { frequency, } 2 \text { years prior) }\end{array}$ & $\begin{array}{l}\text { Favorable: Inversely associated with breast cancer risk } \\
\text { (OR ( } 95 \% \text { CI): T2 vs. T1, } 0.64(0.44-0.93) ; \mathrm{T} 3 \text { vs. T1, } 0.55(0.39-0.76))\end{array}$ & [17] \\
\hline Iranian (Tehranian)/Iran & $\begin{array}{l}\text { Cross-sectional study, part } \\
\text { of the TLG study }\end{array}$ & $\begin{array}{l}\mathrm{N}=2618(\text { male, } 1162 ; \\
\text { female, } 1456)\end{array}$ & $\begin{array}{l}\text { Quartiles: } \\
\text { Q1: } 0.014 \mathrm{mg} / \text { day } \\
\text { Q2: } 0.015-0.027 \mathrm{mg} / \text { day } \\
\text { Q3: } 0.028-0.053 \mathrm{mg} / \text { day } \\
\text { Q4: } 0.054 \mathrm{mg} / \text { day } \\
\text { (FFQ on a daily frequency, } 1 \text { year prior) }\end{array}$ & $\begin{array}{l}\text { Null: Significantly associated with WC, TG, HDL, BG, and MS } \\
\text { Unfavorable: The top quantile of intake }(0.054 \mathrm{mg} / \text { day and more) was } \\
\text { positively associated with high BP (HR }=1.52 ; 95 \% \text { CI: } 1.02-2.27)\end{array}$ & [19] \\
\hline Spanish/Spain & $\begin{array}{l}\text { Cross-sectional study, part } \\
\text { of the PREDIMED study }\end{array}$ & $\begin{array}{l}\mathrm{N}=1000(\text { male, } 479 ; \\
\quad \text { female, 521) }\end{array}$ & $\begin{array}{l}\text { Quintiles: } \\
\text { Q1: } 0.48 \mathrm{mg} / \text { day } \\
\text { Q2: } 1.04 \mathrm{mg} / \text { day } \\
\text { Q3: } 2.04 \mathrm{mg} / \text { day } \\
\text { Q4: } 5.75 \mathrm{mg} / \text { day } \\
\text { (FFQ, } 1 \text { year prior) }\end{array}$ & $\begin{array}{l}\text { Favorable: Significantly decreased CVD risk factors (FBG }(95 \% \text { CI: } \\
-1.033 \text { to }-0.033) ; \text { TG }(95 \% \text { CI: }-1.998 \text { to }-0.029) \text {; and heart rate }(95 \% \text { CI: } \\
-0.467 \text { to }-0.087) \text { ). } \\
\text { Null: Resveratrol intake was not significantly associated with TC, HDL, } \\
\text { LDL and BP }\end{array}$ & [6] \\
\hline Spanish/Spain & $\begin{array}{l}\text { Cross-sectional study, part } \\
\text { of the PREDIMED study }\end{array}$ & $\begin{array}{l}\mathrm{N}=7172(\text { male, } 3249 \\
\quad \text { female, } 3923)\end{array}$ & $\begin{array}{l}\text { Quintiles: } \\
\text { Q1: } 0.48 \mathrm{mg} / \mathrm{d} \\
\text { Q2: } 1.04 \mathrm{mg} / \mathrm{d} \\
\text { Q3: } 2.04 \mathrm{mg} / \text { day } \\
\text { Q4: } 5.75 \mathrm{mg} / \text { day } \\
\text { (FFQ, } 1 \text { year prior) }\end{array}$ & $\begin{array}{l}\text { Favorable: } \text { High dose intake }(5.75 \mathrm{mg} / \mathrm{d}) \text { significantly reduced all-cause } \\
\text { mortality by } 52 \%(\mathrm{HR}=0.48 ; 95 \% \text { CI: } 0.25-0.91) \\
\text { Null: No significant CVD risk reduction (HR }=0.77 ; 95 \% \text { CI: } 0.35-1.72)\end{array}$ & {$[21,22]$} \\
\hline Swedish/Sweden & Case-control study & $\begin{array}{l}\mathrm{N}=1400 \\
\text { (case, 594 including (OAC, } \\
\text { 181; OSCC, 158; JAC, 255)) } \\
\text { (control, 806) }\end{array}$ & $\begin{array}{l}\text { Control: } 0.1 \mathrm{mg} / \text { day } \\
\text { OAC: } 0.07 \mathrm{mg} / \text { day } \\
\text { OSCC: } 0.11 \mathrm{mg} / \text { day } \\
\text { JAC: } 0.09 \mathrm{mg} / \text { day } \\
\text { (FFQ, } 20 \text { years prior) }\end{array}$ & $\begin{array}{l}\text { Favorable: In a significantly negative association with the risk of } 3 \\
\text { subtypes of esophageal cancer (OAC (95\% CI: } 0.12-0.49) \text {; OSCC ( } 95 \% \text { CI: } \\
0.15-0.65) \text {, and JAC ( } 95 \% \text { CI: } 0.28-0.84))\end{array}$ & [5] \\
\hline Italian/Italy & $\begin{array}{l}\text { Cohort study, "Aging in } \\
\text { the Chianti Region" }\end{array}$ & $\begin{array}{c}\mathrm{N}=529 \\
\text { (male, 236; female, 293) }\end{array}$ & $\begin{array}{l}\text { Tertiles: } \\
\text { T1: } 0.1 \mathrm{mg} / \text { day } \\
\text { T2: } 0.1-1.1 \mathrm{mg} / \text { day } \\
\text { T3: }>1.1 \mathrm{mg} / \text { day (FFQ) }\end{array}$ & $\begin{array}{l}\text { Favorable: Inversely associated with the risk of frailty syndrome during } \\
\text { the first 3-year follow-up (T3 vs. T1: OR }=0.11 ; 95 \% \text { CI: 0.03-0.45) } \\
\text { Null: No substantial association with } \\
\text { (i) risk of frailty syndrome in 6-, or 9-year follow-up; } \\
\text { (ii) inflammatory biomarkers including IL-6, IL-1 } \beta, T N F-\alpha \text {, and CRP; } \\
\text { (iii) CVD, cancer or all-cause mortality }\end{array}$ & [18] \\
\hline Chinese/China & Cross-sectional study, & $\begin{array}{l}\mathrm{N}=1393(\text { male, } 446 ; \\
\quad \text { female, } 947)\end{array}$ & $\begin{array}{l}\text { Mean: } 0.15 \mathrm{mg} / \mathrm{d} \\
\text { (FFQ, } 1 \text { year prior) }\end{array}$ & $\begin{array}{l}\text { Null: Not significantly associated with CVD risk factors including BP, } \\
\text { BG, lipid profiles (TC, TG, HDL, and LDL), and carotid IMT }\end{array}$ & [23] \\
\hline
\end{tabular}

Abbreviations used in the table: BG, blood glucose; BP, blood pressure; CI, confidence intervals; CRP, C-reactive protein; FBG, fasting blood glucose; FFQ, food-frequency questionnaire; HDL, high-density lipoprotein; HR, hazard ratios; IL, interleukin; IMT, intima-media thickness; JAC, (gastro-esophageal) junctional adenocarcinoma; LDL, low-density lipoprotein; MORGEN study, Monitoring Project on Risk Factors and Health in the Netherlands study; MS, metabolic syndrome; OAC, esophageal adenocarcinoma; OR: odds ratio; OSCC, esophageal squamous-cell carcinoma; PREDIMED study: Prevención con Dieta Meniterránea study; TC, total cholesterol; TG, triglyceride; TLGS: Tehran lipid and glucose study; TNF- $\alpha$, tumor necrosis factor $\alpha ; W C$, waist circumference. 


\section{Experimental Studies}

Given the observed benefits based on resveratrol consumption, a great deal of research has explored more health outcomes of resveratrol as well as the underlying molecular mechanisms.

\subsection{Antioxidative Activities}

Resveratrol has shown strong antioxidant properties in many studies [24,25]. Resveratrol protects against oxidative stress, one of the primary contributors to many diseases, through various redox-associated molecular pathways (Figure 1 and Table 2). For instance, resveratrol upregulated the phosphatase and tensin homolog (PTEN), which decreased Akt phosphorylation, leading to an upregulation of antioxidant enzyme mRNA levels such as catalase (CAT) and superoxide dismutase (SOD) [26]. Resveratrol could also improve the antioxidant defense system by modulating antioxidant enzymes through downregulation of extracellular signal-regulated kinase (ERK) activated by reactive oxygen species (ROS) [27]. Meanwhile, resveratrol reduced the ischemia-reperfusion injury-induced oxidative stress by inhibiting the activation of the p38 mitogen-activated protein kinase (MAPK) pathway, thus the levels of antioxidants like glutathione (GSH) increased, and free radicals were directly scavenged [28]. Furthermore, resveratrol activated adenosine monophosphate (AMP)-activated protein kinase (AMPK) to maintain the structural stability of forkhead box O1 (FoxO1), facilitate its translocation, and accomplish its transcriptional function [25]. Moreover, resveratrol was demonstrated to improve systemic oxidative and nitrosative stress by activating AMPK, then sirtuin 1 (SIRT1) and the nuclear factor erythroid-2-related factor 2 (Nrf2) associated antioxidant defense pathways, as Nrf2 acts as the master regulator of numerous genes encoding antioxidants and phase II-detoxifying enzymes and molecules [29,30]. Additionally, resveratrol exhibited antioxidant bioactivities by regulating antioxidant gene expression via the Kelch-like ECH-associated protein 1 (Keap1)/Nrf2 pathway and SIRT1 [31]. Recently, resveratrol was reported to attenuate oxidative injury owing to the induced autophagy via the AMPK-mediated inhibition of mammalian target of rapamycin (mTOR) signaling or via the activation of transcription factor EB (TFEB), which promoted the formation of autophagosomes and lysosomes as well as their fusion into an autolysosome [32,33]. Generally, resveratrol protects against oxidative stress mainly by (i) reducing ROS/reactive nitrogen species (RNS) generation; (ii) directly scavenging free radicals; (iii) improving endogenous antioxidant enzymes (e.g., SOD, CAT, and GSH); (iv) promoting antioxidant molecules and the expression of related genes involved in mitochondrial energy biogenesis, mainly through AMPK/SIRT1/Nrf2, ERK/p38 MAPK, and PTEN/Akt signaling pathways; (v) inducing autophagy via mTOR-dependent or TFEB-dependent pathway. 


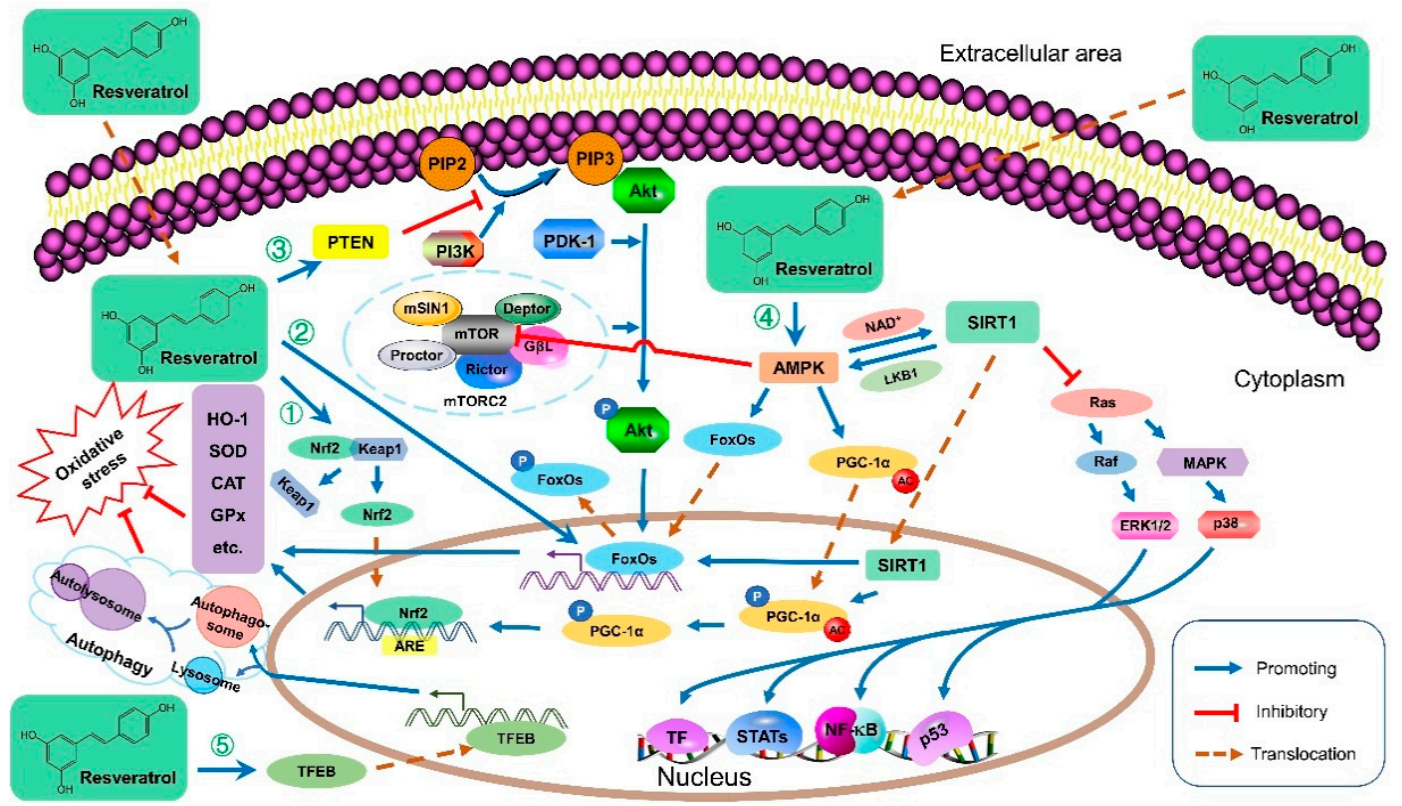

Figure 1. The antioxidant molecular mechanisms of resveratrol. (1) Resveratrol unanchors Nrf2 in the cytoplasm, disrupting its Keap1-dependent ubiquitination and degradation. The built-up Nrf2 translocates into the nucleus, binds to ARE, and initiates the transcription of many antioxidative genes such as SOD and CAT to reduce oxidative stress. (2) Resveratrol promotes the transcriptional functions of FoxOs in the nucleus to facilitate the transcription of many antioxidative genes like HO-1, contributing to the reduction of oxidative stress. (3) Resveratrol upregulated PTEN, a major antagonist of PI3K, blocking the Akt activation. Consequently, the activated Akt reduces, leading to decreased FoxOs phosphorylation. Therefore, less $p$-FoxOs translocate from the nucleus to the cytoplasm, and more FoxOs remain in the nucleus to act as transcriptional factors. (4) Resveratrol activates AMPK to maintain the structural stability of FoxOs, facilitate its translocation, and accomplish its transcriptional function. In addition, the activated AMPK phosphorylates PGC- $1 \alpha$, which can translocate into the nucleus, and be deacetylated by SIRT1. Then PGC-1 $\alpha$ promotes Nrf2, leading to increased antioxidative gene expression and then reduced oxidative stress. Resveratrol activates AMPK, leading to SIRT1 activation, which inhibits MAPK signaling pathways and results in autophagy. (5) Resveratrol induces autophagy by activating TFEB, which promotes the formation of autophagosome and lysosome as well as their fusion into an autolysosome, leading to reduced oxidative stress. Abbreviations: AC, acetyl; Akt, protein kinase B; AMPK, AMP-activated protein kinase; ARE, antioxidant response element; CAT, catalase; ERK, extracellular signal-regulated kinase; FoxO, forkhead box protein O; GPx, glutathione peroxidase; G $\beta$ L, G protein $\beta$ subunit-like; HO-1, heme oxygenase 1; Keap1, Kelch-like ECH-associated protein 1; LKB1, liver kinase B1; MAP2K, mitogen-activated protein kinase kinase; MAPK, mitogen-activated protein kinase; mSIN1, mammalian stress-activated protein kinase interacting protein 1; mTOR, mammalian target of rapamycin; mTORC2, mTOR Complex 2; NAD, nicotinamide adenine dinucleotide; NF- $\mathrm{kB}$, nuclear factor kappa-light-chain-enhancer of activated B cells; Nrf2, nuclear factor (erythroid-derived 2)-like 2; P, phosphorylation; p53, phosphoprotein p53; PDK1, phosphoinositide dependent kinase 1; PGC-1 $\alpha$, peroxisome proliferator-activated receptor gamma coactivator $1 \alpha$; PI3K, phosphatidylinositol 3-kinase; PIP2, phosphatidylinositol 4,5-bisphosphate; PIP3, phosphatidylinositol-3,4,5-trisphosphate; PTEN, phosphatase and tensin homolog; Rictor, the rapamycin-insensitive companion of mTOR; SIRT1, sirtuin 1; SOD, superoxide dismutase; STAT, signal transducer and activator of transcription; TF, transcription factor; TFEB, transcription factor EB.

\subsection{Anti-Inflammatory Activities}

Resveratrol has been illustrated to have potent anti-inflammatory activities in many studies (Table 2) [34-37]. Resveratrol protected from inflammation not only by inhibiting the production of pro-inflammatory cytokines such as tumor necrosis factor $\alpha$ (TNF- $\alpha$ ) and interleukin-1 $\beta$ (IL-1 $\beta$ ), 
but also by inducing anti-inflammatory heme oxygenase-1 (HO-1) in RAW264.7 macrophages [38]. Additionally, resveratrol suppressed IL-6 transcription, modulating the inflammatory responses as an estrogen receptor $\alpha(E R \alpha)$ ligand mediated by SIRT1, which functions as an ER coregulator [39]. Resveratrol could also inhibit nuclear factor kappa-light-chain-enhancer of activated B cells (NF- $\mathrm{kB}$ ) signaling independent of SIRT1 [40]. Moreover, resveratrol attenuated inflammation by downregulating high mobility group box 1 (HMGB1) as well as suppressing NF- $\mathrm{kB}$ and Janus kinase (JAK)/signal transducer and activator of transcription (STAT) signaling pathways [41,42]. In addition, both in vitro and in vivo, the anti-inflammatory effects of resveratrol were associated with its inhibition of the toll-like receptor 4 (TLR4)/NF- $\mathrm{KB}$ signaling cascade $[43,44]$. Furthermore, resveratrol attenuated inflammation by inhibiting the activation of NACHT, LRR, and PYD domains-containing protein 3 (NALP3) inflammasome and inducing autophagy via SIRT1 upregulation and AMPK activation [34,35]. In a study on osteoarthritis, resveratrol interrupted an inflammatory amplification loop [45]. Specifically, the resveratrol-induced NF- $\mathrm{KB}$ inhibition resulted in decreased IL-6 secretion, leading to suppressed signal transducer and activator of transcription 3 (STAT3) activation in macrophages. Since STAT3 was responsible for the positive regulation of IL-6 secretion, inhibition of STAT3 made IL-6 levels even lower. Resveratrol could also block ERK1/2 activation, consequently upregulating MyD88 Short, a negative regulator of inflammation [36]. Altogether, resveratrol was able to regulate the pro- and anti-inflammatory cytokines and chemokines to protect against inflammation, mainly by upregulating SIRT1, suppressing NF- $\mathrm{kB}$, and the associated cascades, as well as inhibiting NALP3 inflammasome activation.

\subsection{Immunomodulating Effects}

Resveratrol has exerted immunomodulating effects in various studies (Table 2) [46-48]. Resveratrol modulates immune response against pathogens like viruses, bacteria, and some toxic materials. For instance, resveratrol upregulated immune responses and reduced immunocyte apoptosis in chickens receiving conventional vaccinations and improved the growth of young chickens [49]. Resveratrol also reduced the activity of respiratory syncytial virus and inhibited the toll/IL-1 receptor domain-containing adaptor inducing $\beta$ interferon (TRIF) expression through upregulating sterile $\alpha$ and armadillo motif protein (SARM) [50]. In addition, resveratrol prevented enterovirus 71 (EV71) replication and reduced the virus-induced elevated IL- 6 and TNF- $\alpha$ secretion in rhabdosarcoma cells via suppressing IкB kinase (IKK)/NF- $\kappa B$ signaling pathway [48]. Moreover, resveratrol inhibited human rhinoviruses-16 replication and normalized virus-induced IL-6, IL-8 and regulated on activation normal T cell expressed and secreted (RANTES) as well as the expression of intercellular adhesion molecule-1 (ICAM-1) [47]. Additionally, resveratrol maintained the immune function in rotavirus-infected piglets, resulting in attenuated diarrhea and inflammation [51]. Moreover, resveratrol triggered an immune response to protect against non-typeable Haemophilus influenzae (a respiratory bacterium) without developing resistance in vitro [46]. Resveratrol also decreased bacterial viability and reduced infectious airway inflammation without noticeable host toxicity in vivo [46,52]. In addition, resveratrol showed immunomodulatory properties via reducing bacterial and inflammatory biomarkers in lipopolysaccharides (LPS)-challenged primary Atlantic salmon macrophages [52]. Resveratrol also modulated immunity caused by some toxic materials like concanavalin A (Con A), showing upregulation of SIRT1 and reduction of cytokines such as TNF- $\alpha$, interferon $\gamma$ (IFN- $\gamma$ ), IL-6, and monocyte chemoattractant protein-1 (MCP-1) [53]. Interestingly, resveratrol was found to strongly enhance immune activity in immunosuppressive mice, showing a bidirectional regulatory effect on immunity [54]. Specifically, resveratrol improved spleen lymphocyte proliferation, enhanced the function of peritoneal macrophages, and increased the $\mathrm{CD} 4^{+}$cells in peripheral blood. Furthermore, some cytokines in the serum were upregulated, such as IL- $1 \alpha / \beta$, IL-2, and TNF- $\alpha$. Based on a statistical analysis of human microarray data, a recent study revealed that resveratrol regulated many immune response pathways including peroxisome proliferator-activated receptor $\alpha$ (PPAR- $\alpha$ )/retinoid $\mathrm{X}$ receptor $\alpha(\mathrm{RXR} \alpha)$ activation, IL-10 signaling, natural killer cell signaling, leucocyte extravasation 
signaling, and IL-6 signaling [55]. Recently, it was revealed that resveratrol could suppress the aryl hydrocarbon receptor (AhR) pathway, resulting in the reversal of imbalanced Th17/Treg, the main characteristic of immune thrombocytopenic purpura [56].In short, resveratrol could modulate both cellular and humoral immunity to reduce replication and the viability of pathogens, and bidirectionally regulate the related cytokine/chemokine production through the canonical immune response pathways as mentioned above.

\subsection{Cardiovascular Diseases}

Resveratrol has been reported to protect against CVDs in certain research (Table 2) [57-59]. Resveratrol prevented the pathological progression of hypertension, a major risk factor of CVDs, through Nrf2 activation, owing to its antioxidant and anti-inflammatory capacity [60]. Resveratrol could also lower blood pressure in hypertensive mice by inducing oxidative activation of cyclic guanosine monophosphate (cGMP)-dependent protein kinase $1 \alpha$ (PKG1 $\alpha)$ [61]. Atherosclerosis is another main contributor to CVDs. Resveratrol was able to block atherosclerotic plaque progression by acting against pro-atherogenic oxysterol signaling in M1 (inflammation-encouraging) and M2 (inflammation-decreasing) macrophages [57]. Meanwhile, resveratrol prevented the activation of inflammasome, a contributor to the vascular inflammatory injury and atherosclerosis, via downregulating NF- $\mathrm{kB}$ p65 and p38 MAPK expression, and upregulating SIRT1 expression [62]. In addition, resveratrol ameliorated atherosclerosis partially through restoring intracellular GSH via AMPK- $\alpha$ activation, resulting in inhibited monocyte differentiation and reduced pro-inflammatory cytokine production [59]. Moreover, resveratrol regulated the band 4.1, ezrin, radixin, and moesin (FERM)-kinase and Nrf2 interaction, leading to decreased expression of ICAM-1 and then the inhibition of monocyte adhesion [63]. Resveratrol also exhibited antithrombotic effects via decreasing the tissue factors like TNF- $\alpha$, and such action could be facilitated by aortic endothelial cells that could deconjugate resveratrol metabolites to free resveratrol [64]. Furthermore, one of the atherosclerosis consequences, high fat/sucrose diet-induced central arterial wall stiffening, was improved by resveratrol based on its protective activities against oxidative stress and inflammation [7]. Resveratrol also effectively prevented CVD by improving the cardiac and vascular autonomic function, protecting the erythrocytes via interacting with hemoglobin and reducing heme-iron oxidation $[65,66]$. In a heart failure model, resveratrol mitigated atrial fibrillation by upregulating PI3K and endothelial NOS (eNOS) [8]. In summary, the cardiovascular protective effects of resveratrol mainly depend on the capabilities of reducing oxidative stress and alleviating inflammation through Nrf2 and/or SIRT1 activation, PI3K/eNOS upregulation, and NF- $\mathrm{kB}$ downregulation.

\subsection{Cancers}

Resveratrol has exhibited protective impacts on various cancers, like colorectal cancer, lung cancer, breast cancer, prostate cancer, ovarian cancer, cervical cancer, liver cancer, and gastric cancer (Table 2) [14,67-71]. For instance, resveratrol was reported to inhibit the formation and growth of colorectal cancer by downregulating oncogenic KRAS expression [68]. Resveratrol also prevented tumorigenesis and progression of non-small cell lung cancer (NSCLC) cells by interrupting glycolysis via inhibition of hexokinase II expression, which was mediated by downregulation of the epidermal growth factor receptor (EGFR)/Akt/ERK1/2 signaling pathway [69]. Moreover, resveratrol showed pro-apoptotic/anti-proliferative effects in LNCaP cells (human prostate adenocarcinoma cells) through inducing the expression of cyclooxygenase (COX)-2, promoting ERK1/2 activation, and facilitating p53-dependent anti-proliferation gene expression [14]. In addition, resveratrol could decrease the efficiency of ovarian cancer cells adhering to peritoneal mesothelium in vitro by downregulating the production of $\alpha 5 \beta 1$ integrins and upregulating the release of soluble hyaluronic acid [70]. Resveratrol was also reported to inhibit the expression of phospholipid scramblase 1 (PLSCR1), leading to the growth inhibition of HeLa cells [71]. Furthermore, resveratrol showed proliferation-inhibitory and apoptosis-inducing effects in HepG2 cells by activating caspase- 3 and caspase- 9 , upregulating the 
Bax/Bcl-2 ratio, and inducing p53 expression [72]. Resveratrol also inhibited the invasion and migration of human gastric cancer cells by blocking the epithelial-to-mesenchymal transition, which was mediated by metastasis-associated lung adenocarcinoma transcript 1 (MALAT1) [73]. Additionally, resveratrol protected against breast cancer metastasis by promoting antitumor immune responses via blunting STAT3, leading to inhibited generation and function of tumor-evoked regulatory B cells (tBregs) as well as decreased production of transforming growth factor $\beta$ (TGF- $\beta$ ) (a downstream target of STAT3), which was required by the tBregs to convert resting $\mathrm{CD} 4^{+} \mathrm{T}$ cells to the metastasis-promoting $\mathrm{FoxP}^{+}$ regulatory T cells (Tregs) [67]. Although some research showed that resveratrol may be beneficial in breast cancer chemoprevention due to its non-estrogen function [74], different doses of resveratrol showed controversial effects due to its interaction with estrogens, which induce cellular proliferation and play a key role in breast cancer development and progression. Specifically, it was found that high concentrations of resveratrol could inhibit the proliferation of estrogen receptor alpha positive $(\mathrm{ER} \alpha+)$ breast cancer, while low concentrations increased the growth of ER $\alpha+$ cells $[75,76]$. It was reported that at low concentrations, resveratrol not only bound to ERs due to its structural similarity with E2, but also increased the formation of estrogen precursor steroids and inhibited the inactivation of active steroids, resulting in elevated active estrogen levels, leading to breast cancer cell growth and progression $[77,78]$. However, "more resveratrol is better" was challenged in some cases [79]. For instance, in terms of colorectal cancer chemoprevention, lower doses of resveratrol from dietary exposures exerted a better efficacy than high doses (200 times higher previously used in phase I clinical trials) due to its pro-oxidant activity at high doses and AMPK signaling upregulation.

Collectively, resveratrol has shown its anticancer bioactivities by impairing glycolysis, inhibiting cancer cell growth and proliferation, inducing apoptosis, promoting antitumor immune responses, and preventing adhesion, migration and invasion of cancer cells by modulating related molecules and gene expression through various signaling pathways. Of note, different doses may lead to very different effects, which sometimes could be opposite. Therefore, consideration regarding doses and matrix should be paid more attention in future studies.

\subsection{Liver Diseases}

Resveratrol has shown its protective impacts on several liver diseases in some studies (Table 2) [9,80-82]. Specifically, resveratrol alleviated non-alcoholic fatty liver disease (NAFLD) by upregulating the low-density lipoprotein receptor (LDLR) and scavenger receptor class B type I (SRB1) gene expressions in the liver [83], or by regulating autophagy and decreasing the activity of $\mathrm{NF}-\mathrm{kB}$, resulting from restoring its inhibitor, nuclear factor of kappa light polypeptide gene enhancer in B-cells inhibitor $\alpha(\mathrm{I} \kappa \mathrm{B} \alpha)$ [84]. Resveratrol also improved high-fat diet (HFD)-induced fatty liver by downregulating adipose differentiation-related proteins and increasing the numbers of $\mathrm{CD} 68^{+}$ Kupffer cells [9]. As for chemical-induced liver diseases, resveratrol could markedly restore the morphology and function of alcohol-injured liver through inducing autophagy, or downregulating hypoxia-inducible factor $1 \alpha$ (HIF-1 $\alpha$ ) expression [85,86]. In addition, resveratrol ameliorated $\mathrm{CCl}_{4}$-induced liver injury by blocking the Notch signaling pathway [82]. Furthermore, resveratrol attenuated $\mathrm{N}^{\prime}$-Nitrosodimethylamine-induced hepatic fibrosis by restoring the architecture and normalizing collagen deposition, mainly due to its antioxidative activities and downregulation of smooth muscle actin $(\alpha-$ SMA), which suppressed hepatic stellate cell activation $[80,81]$. Moreover, resveratrol pretreatment mitigated liver cirrhosis by improving the homing of bone marrow-derived mesenchymal stem cells [87]. In summary, resveratrol could improve NAFLD, chemical-induced liver injuries, fibrosis, and cirrhosis by modulating redox status, regulating lipid metabolism, ameliorating inflammation, and inducing autophagy with various cytokines, chemokines, and transcription factors involved.

\subsection{Diabetes}

Resveratrol has been elicited to attenuate diabetes and its relevant complications in many studies (Table 2) [88-91]. Resveratrol was observed to significantly reduce blood glucose levels, 
plasma lipids, and free fatty acids in diabetic mice, and it inhibited the expression of inflammatory mediators (e.g., ICAM-1, vascular cell adhesion molecule-1, and MCP-1) both in the aorta and in the blood, by inhibiting the NF-KB pathway [92]. In addition, resveratrol could relieve diabetes via increasing insulin action and glucose utilization due to visfatin expression restoration, SIRT1 activation, and glucose transporter modulation [89]. Moreover, resveratrol increased glucose uptake to improve insulin resistance in the muscle by decreasing diacylglycerol (DAG) accumulation and protein kinase $\mathrm{C} \theta$ (PKC- $\theta$ ) translocation, and preventing lipolysis under the condition of adipose hypoxia, because resveratrol could preserve phosphodiesterase $3 \mathrm{~B}$ expression (PDE 3B) to downregulate cyclic adenosine monophosphate (cAMP), leading to the inhibition of protein kinase A (PKA)/hormone-sensitive lipase (HSL) activation [90]. Moreover, resveratrol showed protective effects on adipose tissue in diabetic mice by preventing ROS-mediated mitochondrial fission via AMPK-dependent upregulation of Drp1 phosphorylation, and by blocking the activation of NALP3 inflammasome via inhibition of endoplasmic reticulum stress (ERS) [93]. Resveratrol also protected against diabetic complications such as myocardial fibrosis, diabetic nephropathy, and erectile dysfunction [11,88,94]. Furthermore, maternal resveratrol administration to the rats was evidenced to prevent the offspring's glucose intolerance and islet dysfunction, which were associated with gestational diabetes [91]. In summary, resveratrol could effectively regulate glucose metabolism, improve insulin resistance, improve diabetic complications, and restore the function of multiple systems via modulating SIRT1/NF- $\mathrm{KB} / \mathrm{AMPK}$ signaling pathways and some associated molecules like NALP3 inflammasome, as well as the expressions of relevant genes.

\subsection{Obesity}

Obesity has become a severe health issue globally. Resveratrol significantly decreased the body weight and fat mass in mice with HFD-induced obesity, showing reduced leptin and lipids in plasma, modulated metabolism of glucose and insulin, and restored immune dysfunction, via the activation of PI3K/SIRT1 and Nrf2 signaling pathways, and the inhibition of transcriptional regulators (e.g., EP300 gene), which are involved in the differentiation of adipocytes as well as lipid storage and metabolism $[95,96]$. Moreover, besides a significant dose-dependent decrease of weight gain and lipid deposition in the liver and adipose tissues of HFD-induced obese mice, low concentrations of resveratrol (1-10 $\mu \mathrm{M})$ suppressed adipogenic differentiation in pre-adipocytes, downregulated the expression of peroxisome proliferator-activated receptor $\gamma$ (PPAR- $\gamma$ ) and perilipin protein in differentiated adipocytes, and inhibited TNF- $\alpha$-induced lipolysis in mature adipocytes [97]. Additionally, resveratrol prevented against obesity through markedly enhancing the catecholamine production, accompanied by suppressing the pro-inflammatory M1 macrophages and activating anti-inflammatory M2 macrophages in white adipose tissue, which play a pivotal role in the trans-differentiation of white adipocytes into beige adipocytes [98]. Furthermore, resveratrol administrated to the pregnant and lactating mice led to promoted white adipose browning and thermogenesis in the male descendants, and these health benefits persisted and prevented obesity in their future life [99]. In addition, resveratrol protected against sarcopenic obesity by improving mitochondrial function and reducing oxidative stress through the PKA/liver kinase B1 (LKB1)/AMPK pathway [100]. Resveratrol also showed positive impacts on obesity-related complications, such as reproductive dysfunction like infertility and endocrine disorders $[101,102]$. To summarize, resveratrol has been illustrated to decrease body weight, regulate lipid deposition, modulate adipocyte gene expression, and promote white adipose browning, via PI3K/SIRT1, Nrf2, PPAR- $\gamma$, TNF- $\alpha$, and PKA/LKB1/AMPK signaling pathways (Table 2).

\subsection{Alzheimer's Disease and Parkinson's Disease}

Alzheimer's disease and Parkinson's disease are neurodegenerative disorders, seriously decreasing life quality, while resveratrol may have the potential to improve these diseases. For instance, resveratrol inhibited the aggregation of amyloid $\beta(\mathrm{A} \beta)$, a key factor in Alzheimer's disease, by modulating specific proteins such as ubiquitin-like protein (UBL)/X-box binding protein 1 (XBP-1) involved in proteostasis [103]. Furthermore, resveratrol prevented memory loss in Alzheimer's disease by 
decreasing elevated levels of mitochondrial complex IV protein in the mouse brain via the activation of SIRT1 and AMPK pathways [104,105]. In terms of Parkinson's disease, resveratrol ameliorated ERS by downregulating the gene expression of C/EBP homologous protein (CHOP) and glucose-regulated protein 78 (GRP78), inhibiting caspase-3 activity in the rat brain, and ameliorating oxidative damage via suppressing xanthine oxidase activity and protein carbonyl formation as well as activating the glutathione peroxidase and Nrf2 signaling pathway [10]. Resveratrol also alleviated Parkinson's disease through elevating miR-214 expression, leading to decreased mRNA expression of $\alpha$-synuclein [106]. Taken together, resveratrol ameliorated Alzheimer's disease and Parkinson's disease by activating the SIRT1, AMPK, and Nrf2 signaling pathways and modulating the associated gene expressions (Table 2).

\subsection{Sex-Dependent Effects of Resveratrol}

Acting as an estrogen agonist, resveratrol showed sex-dependent effects on some diseases, which causes increasing concerns (Table 2). CVD risk increases with increasing age, gradually in men while disproportionately in women, and such a lower risk was in association with estrogen's cardioprotective properties $[107,108]$. In a recent in vivo study, sex differences were observed in rats with surgically-induced myocardial infarction (MI) due to the resveratrol treatment $(2.5 \mathrm{mg} / \mathrm{kg} / \mathrm{d})$ [109]. Superior improvements were observed in females in terms of interventricular septal wall dimension at systole (IVSDs), end-systolic volume (ESV), ejection fraction (EF), fractional shortening (FS), and isovolumic relaxation time (IVRT), among which IVRT was purely sex-dependent. In another study, long-term resveratrol treatment in rats $(50 \mathrm{mg} / \mathrm{L}$ in drinking water, 21 days) increased the relaxations to estrogen in aortae, more potently in males, probably due to the effects of resveratrol on promoting nitric oxide and/or suppressing superoxides [110]. Alongside this, it was revealed that resveratrol $(20 \mathrm{mg} / \mathrm{kg}$ ) significantly increased dopamine transporter (DAT) in the striatum in female but not in male mice [111]. The in vitro study in the same research indicated that resveratrol upregulated DAT in the dopaminergic cells by inducing its gene transcription. Additionally, sex differences in the effect of resveratrol were also found in a mouse model of dextran sulfate sodium-induced colitis [112]. Adverse effects were observed in females but not in males, regarding weight loss, stool consistency, and discomfort. Such results indicate that special attention should be paid to the application of resveratrol, a phytoestrogen, which can interact with hormone receptors and result in sex-dependent effects that can be beneficial or harmful. 
Table 2. Bioactivities and potential mechanisms of resveratrol from experimental studies.

\begin{tabular}{|c|c|c|c|c|}
\hline Study Type & Subject & Dose & Main Findings & Ref. \\
\hline \multicolumn{5}{|c|}{ Antioxidative activities } \\
\hline In vitro & HepG2 cells & $0-100 \mu \mathrm{M}$ & $\begin{array}{l}\text { Dose-dependently increasing antioxidant effects by enhancing SIRT2's activity } \\
\text { to deacetylate Prx1 }\end{array}$ & [24] \\
\hline In vitro & $\begin{array}{l}\text { HepG2, } \\
\text { C2C12, and HEK293 cells }\end{array}$ & $10,25 \mu \mathrm{M}$ & Activating AMPK to maintain the structural stability of FoxO1 & [25] \\
\hline In vitro & MCF-7 cells & $\begin{array}{c}1 \mathrm{nM}, 0.02 \mu \mathrm{M}, 0.1 \mu \mathrm{M}, 0.5 \mu \mathrm{M}, \\
1.5 \mu \mathrm{M}\end{array}$ & $\begin{array}{l}\text { Upregulating PTEN (except at the highest dose, } 1.5 \mu \mathrm{M} \text { ), which decreased Akt } \\
\text { phosphorylation, leading to an upregulation of antioxidant enzyme mRNA } \\
\text { levels such as CAT and SOD }\end{array}$ & [26] \\
\hline In vivo & Rats & 20 mg kg/b.w./day & $\begin{array}{l}\text { Improving the antioxidant defense system by modulating antioxidant } \\
\text { enzymes through downregulation of ERK activated by ROS }\end{array}$ & [27] \\
\hline In vivo & Rats & $10 \mathrm{mg} / \mathrm{kg}$ b.w. & $\begin{array}{l}\text { Reducing the ischemia-reperfusion injury-induced oxidative stress by } \\
\text { inhibiting the activation of p } 38 \text { MAPK pathway to increase antioxidants like } \\
\text { GSH and scavenge free radicals }\end{array}$ & [28] \\
\hline In vivo & Rats & $5,10 \mathrm{mg} / \mathrm{kg}$ & Activating SIRT1 to scavenge ROS & [29] \\
\hline In vivo & Mice & $15,30,60 \mathrm{mg} / \mathrm{kg}$ & $\begin{array}{l}\text { Activating AMPK, SIRT1, and Nrf2 associated antioxidant defense pathways } \\
\text { to improve systemic oxidative and nitrosative stress }\end{array}$ & [30] \\
\hline In vivo & Sows & $300 \mathrm{mg} / \mathrm{kg}$ & Regulating antioxidant gene expression via Keap1/Nrf2 pathway and SIRT1 & [31] \\
\hline In vitro & HUVECs & $10 \mu \mathrm{M}$ & Inducing autophagy via the activation of TFEB & [32] \\
\hline In vitro & HEK293 cells or HEK293T & $5 \mu \mathrm{g} / \mathrm{mL}$ & Inducing autophagy via the AMPK-mediated inhibition of mTOR signaling & [33] \\
\hline \multicolumn{5}{|c|}{ Anti-inflammatory activities } \\
\hline In vivo & Mice & $8 \mathrm{mg} / \mathrm{kg} /$ day & $\begin{array}{l}\text { Inhibiting the activation of NALP3 inflammasome and inducing autophagy } \\
\text { via SIRT1 upregulation }\end{array}$ & [34] \\
\hline In vitro & $\begin{array}{l}\text { J774 mouse macrophages, } \\
\text { Mouse bone-marrow cells }\end{array}$ & $0.5-100 \mu \mathrm{M}$ & Inhibiting the activation of NALP3 inflammasome & [35] \\
\hline $\begin{array}{l}\text { In vitro; } \\
\text { In vivo }\end{array}$ & $\begin{array}{l}\text { BEAS-2B cells, } \\
\text { Mice }\end{array}$ & $\begin{array}{c}25 \mu \mathrm{M}, \\
20 \mathrm{mg} / \mathrm{kg}\end{array}$ & $\begin{array}{l}\text { Inducing NF-kB inhibition, decreasing IL-6 secretion, suppressing STAT3 } \\
\text { activation, blocking ERK1/2 activation, and upregulating MyD88 Short }\end{array}$ & [36] \\
\hline In vitro & RAW264.7 macrophages & $0-20 \mu \mathrm{M}$ & $\begin{array}{l}\text { Inhibiting the production of pro-inflammatory cytokines, such as TNF- } \alpha \text { and } \\
\text { IL- } 1 \beta \text {, but also by inducing anti-inflammatory HO- } 1\end{array}$ & [38] \\
\hline In vitro & RAW264.7 macrophages, MCF-7 cells & $10 \mu \mathrm{M}$ & $\begin{array}{l}\text { Suppressing IL- } 6 \text { transcription, modulating the inflammatory responses as an } \\
\text { ER } \alpha \text { ligand mediated by SIRT1. }\end{array}$ & [39] \\
\hline In vitro & Mouse $\mathrm{C} 2 \mathrm{C} 12$ myoblasts & $20,50,100 \mu \mathrm{M}$ & Inhibiting NF-kB signaling independent of SIRT1 & [40] \\
\hline
\end{tabular}


Table 2. Cont.

\begin{tabular}{|c|c|c|c|c|}
\hline Study Type & Subject & Dose & Main Findings & Ref. \\
\hline In vitro & RAW264.7 macrophages & $1,5,10,20,40 \mu \mathrm{M}$ & $\begin{array}{l}\text { Downregulating HMGB1 as well as suppressing NF- } \mathrm{kB} \text { and JAK/STAT } \\
\text { signaling pathways }\end{array}$ & [41] \\
\hline In vitro & U937 monocytic cells & $15,30,50 \mu \mathrm{M}$ & Inhibiting NF-KB and JAK/STAT signaling pathways & [42] \\
\hline $\begin{array}{l}\text { In vitro } \\
\text { In vivo }\end{array}$ & $\begin{array}{l}\text { NRK-52E, } \\
\text { Rat }\end{array}$ & $\begin{array}{c}100 \mu \mathrm{mol} / \mathrm{mL} \\
0.23 \mu \mathrm{g} / \mathrm{kg}\end{array}$ & Inhibiting TLR4/NF- $\mathrm{kB}$ signaling cascade & [43] \\
\hline In vivo & Rats & 30,10 and $3 \mathrm{mg} / \mathrm{kg}$, & Inhibiting TLR4/NF-kBp65/MAPKs signaling cascade & [44] \\
\hline In vitro & Primary chondrocytes and macrophages & $10,25,50,100 \mu \mathrm{M}$ & Interrupting an inflammatory amplification loop & [45] \\
\hline \multicolumn{5}{|c|}{ Immunomodulating effects } \\
\hline In vitro & A549 cells & $56.25,112.5 \mu \mathrm{g} / \mathrm{mL}$ & $\begin{array}{l}\text { Triggering an immune response to protect against non-typeable Haemophilus } \\
\text { influenzae without developing resistance }\end{array}$ & [46] \\
\hline In vitro & H1HeLa cells, Human nasal epithelia & $0-300 \mu \mathrm{M}$ & $\begin{array}{l}\text { Inhibiting human rhinoviruses- } 16 \text { replication and normalized virus-induced } \\
\text { IL-6, IL-8, and RANTES as well as the expression of ICAM-1 }\end{array}$ & [47] \\
\hline In vitro & Rhabdosarcoma cells & $2.5-100 \mu \mathrm{g} / \mathrm{mL}$ & $\begin{array}{l}\text { Preventing EV71 replication, reducing the virus-induced elevated IL- } 6 \text { and } \\
\text { TNF- } \alpha \text { secretion via suppressing IKK/NF- } \kappa B \text { signaling pathway }\end{array}$ & [48] \\
\hline In vivo & Chickens & $200,400,800 \mathrm{mg} / \mathrm{kg}$ & $\begin{array}{l}\text { Reducing immunocyte apoptosis in chickens receiving conventional } \\
\text { vaccinations, and improving the growth of young chickens }\end{array}$ & [49] \\
\hline In vivo & Piglets & $3,10,30 \mathrm{mg} / \mathrm{kg} / \mathrm{d}$ & Maintaining the immune function and attenuating diarrhea and inflammation & [51] \\
\hline In vitro & Atlantic salmon macrophages & $10,30,50 \mu \mathrm{M}$ & $\begin{array}{l}\text { Reducing bacterial and inflammatory biomarkers in LPS-challenged primary } \\
\text { Atlantic salmon macrophages }\end{array}$ & [52] \\
\hline In vivo & Mice & $30 \mathrm{mg} / \mathrm{kg}$ & $\begin{array}{l}\text { Upregulating SIRT1 and reducing cytokines such as TNF- } \alpha \text {, IFN- } \gamma \text {, IL- } 6 \text {, } \\
\text { and MCP-1 }\end{array}$ & [53] \\
\hline In vivo & Mice & $30 \mathrm{mg} / \mathrm{kg}$ & $\begin{array}{l}\text { Enhancing immune activity in immunosuppressive mice, showing a } \\
\text { bidirectional regulatory effect on immunity }\end{array}$ & [54] \\
\hline In vitro & Human CD4+ T cells & 10,30 , or $50 \mu \mathrm{M}$ & $\begin{array}{l}\text { Suppressing the AhR pathway, resulting in the reversal of imbalanced } \\
\text { Th17/Treg }\end{array}$ & [56] \\
\hline \multicolumn{5}{|c|}{ Cardiovascular diseases } \\
\hline In vivo & Rhesus monkeys & $\begin{array}{l}80 \mathrm{mg} / \text { day (1st year), } \\
480 \mathrm{mg} / \text { day (2nd year) }\end{array}$ & $\begin{array}{l}\text { Improving central arterial wall stiffening based on its antioxidative and } \\
\text { anti-inflammation }\end{array}$ & [7] \\
\hline In vivo & Rabbits & $2.5 \mathrm{mg} / \mathrm{kg}$ & Mitigating atrial fibrillation by upregulating PI3K/AKT/eNOS & [8] \\
\hline In vitro & $\begin{array}{l}\text { Peripheral blood mononuclear } \\
\text { cells }\end{array}$ & $3-80 \mu \mathrm{M}$ & $\begin{array}{l}\text { Blocking atherosclerotic plaque progression by acting against pro-atherogenic } \\
\text { oxysterol signaling in M1 and M2 macrophages }\end{array}$ & [57] \\
\hline
\end{tabular}


Table 2. Cont

\begin{tabular}{|c|c|c|c|c|}
\hline Study Type & Subject & Dose & Main Findings & Ref. \\
\hline $\begin{array}{l}\text { In vitro } \\
\text { In vivo }\end{array}$ & $\begin{array}{l}\text { THP-1 monocytes, } \\
\text { Mice }\end{array}$ & $\begin{array}{c}0,25,50,100 \mu \mathrm{M} \\
\text { (dose-dependent), } \\
10 \mathrm{mg} / \mathrm{kg} / \text { day }\end{array}$ & $\begin{array}{l}\text { Ameliorating atherosclerosis partially through restoring intracellular GSH via } \\
\text { AMPK- } \alpha \text { activation, inhibiting monocyte differentiation, and reducing } \\
\text { pro-inflammatory cytokine production }\end{array}$ & [59] \\
\hline In vivo & Rats & $50 \mathrm{mg} / \mathrm{L}$ & $\begin{array}{l}\text { Preventing the pathological progression of hypertension through } \\
\text { Nrf2 activation }\end{array}$ & [60] \\
\hline $\begin{array}{l}\text { In vitro; } \\
\text { In vivo }\end{array}$ & $\begin{array}{l}\text { Rat aortic smooth muscle cells; } \\
\text { Mice }\end{array}$ & $\begin{array}{l}100 \mu \mathrm{mol} / \mathrm{L} \\
\sim 320 \mathrm{mg} / \mathrm{kg}\end{array}$ & $\begin{array}{l}\text { Lowering blood pressure by inducing oxidative activation of } \\
\text { cGMP-dependent PKG1 } \alpha\end{array}$ & [61] \\
\hline In vivo & Rats & $50 \mathrm{mg} / \mathrm{kg} /$ day & $\begin{array}{l}\text { Preventing the activation of inflammasome via downregulating NF- } \mathrm{kB} \text { p65 } \\
\text { and p38 MAPK expression, and upregulating SIRT1 expression }\end{array}$ & [62] \\
\hline In vivo & Mice & $20 \mathrm{mg} / \mathrm{kg}$ & $\begin{array}{l}\text { Regulated the FERM-kinase and Nrf2 interaction, decreasing the expression of } \\
\text { ICAM-1, and inhibiting monocyte adhesion }\end{array}$ & [63] \\
\hline In vivo & Rats & $1.24 \mu \mathrm{g} / \mathrm{d}$ & Improving the cardiac and vascular autonomic function & [65] \\
\hline In vitro & Human RBCs & $100 \mu \mathrm{M}$ & $\begin{array}{l}\text { Protecting the erythrocytes via interacting with hemoglobin and reducing } \\
\text { heme-iron oxidation }\end{array}$ & [66] \\
\hline \multicolumn{5}{|l|}{ Cancers } \\
\hline In vitro & LNCaP cells & $5,10,20,50 \mu \mathrm{M}$ & $\begin{array}{l}\text { Inducing the expression of COX-2, promoting ERK } 1 / 2 \text { activation, and } \\
\text { facilitating p53-dependent anti-proliferation gene expression }\end{array}$ & [14] \\
\hline $\begin{array}{l}\text { In vitro; } \\
\text { In vivo }\end{array}$ & $\begin{array}{l}\text { tBregs; } \\
\text { Mice }\end{array}$ & $\begin{array}{c}12.5 \mu \mathrm{M} ; \\
20,50,500 \mu \mathrm{g} / \text { mouse }\end{array}$ & $\begin{array}{l}\text { Preventing breast cancer metastasis by promoting antitumor immune } \\
\text { responses via blunting STAT3, leading to inhibited generation and function of } \\
\text { tBregs as well as decreased production of TGF- } \beta\end{array}$ & [67] \\
\hline In vivo & Mice & $150,300 \mathrm{ppm}$ & $\begin{array}{l}\text { Inhibiting the formation and growth of colorectal cancer by downregulating } \\
\text { oncogenic KRAS expression }\end{array}$ & [68] \\
\hline $\begin{array}{l}\text { In vitro; } \\
\text { In vivo }\end{array}$ & $\begin{array}{l}\text { NSCLC cells } \\
\text { Mice }\end{array}$ & $\begin{array}{l}25,50,100 \mu \mathrm{M}, \\
30 \mathrm{mg} / \mathrm{kg} \text { every } 3 \text { days }\end{array}$ & $\begin{array}{l}\text { Preventing tumorigenesis and progression by interrupting glycolysis via } \\
\text { inhibition of hexokinase II expression, which was mediated by } \\
\text { downregulation of EGFR/Akt/ERK1/2 signaling pathway }\end{array}$ & [69] \\
\hline In vitro & $\begin{array}{l}\text { MCF-7 cells } \\
\text { MVLN cells }\end{array}$ & $\begin{array}{l}\text { Low: } 0.1 \text { and } 1 \mu \mathrm{M} \text {; High: } \\
10 \text { and } 25 \mu \mathrm{M} \text {; }\end{array}$ & $\begin{array}{l}\text { Low concentrations: Increasing the growth of ER } \alpha+\text { cells } \\
\text { High concentrations: Inhibiting the proliferation of eER } \alpha+\text { breast cancer }\end{array}$ & [75] \\
\hline In vitro & KPL-1, MCF-7, MKL-F cells & $\begin{array}{l}\text { Low (KPL-1, } \leq 22 \mu \mathrm{M} ; \text { MCF-7, } \\
\leq 4 \mu \mathrm{M}) ; \text { High: } \geq 44 \mu \mathrm{M}\end{array}$ & $\begin{array}{l}\text { Low concentrations: Causing cell proliferation ER+ cells } \\
\text { High concentrations: Suppressing cell growth }\end{array}$ & [76] \\
\hline $\begin{array}{l}\text { In vitro } \\
\text { In vivo }\end{array}$ & $\begin{array}{l}\text { Apc10.1 cells; } \\
\text { Mice; } \\
\text { Humans }\end{array}$ & $\begin{array}{l}0.001-1 \mu \mathrm{M} ; \\
0.7,14.3 \mathrm{mg} / \mathrm{kg} \text { diet; } \\
5 \mathrm{mg}, 1 \mathrm{~g}\end{array}$ & $\begin{array}{l}\text { Lower doses of resveratrol: Showing superior efficacy than high doses due to } \\
\text { the pro-oxidant activity and AMPK signaling upregulation }\end{array}$ & [79] \\
\hline
\end{tabular}


Table 2. Cont.

\begin{tabular}{|c|c|c|c|c|}
\hline Study Type & Subject & Dose & Main Findings & Ref. \\
\hline In vitro & A2780, OVCAR-3, SKOV-3 cells & $10,50,100 \mu \mathrm{M}$ & $\begin{array}{l}\text { Decreasing the efficiency of ovarian cancer cells adhering to peritoneal } \\
\text { mesothelium by downregulating the production of } \alpha 5 \beta 1 \text { integrins and } \\
\text { upregulating the release of soluble hyaluronic acid }\end{array}$ & [70] \\
\hline In vitro & Hela cells & $\begin{array}{r}0.1,1,10 \mu \mathrm{M} \\
10,20,50,100 \mu \mathrm{M}\end{array}$ & $\begin{array}{l}\text { Inhibiting the expression of PLSCR1, leading to the growth inhibition of } \\
\text { HeLa cells }\end{array}$ & [71] \\
\hline In vitro & HepG2 cells & $25,50,100,200 \mu \mathrm{M}$ & $\begin{array}{l}\text { Inhibiting proliferation and inducing apoptosis by activating caspase- } 3 \text { and } \\
\text { caspase- } 9 \text {, upregulating the Bax/Bcl-2 ratio, and inducing p } 53 \text { expression }\end{array}$ & [72] \\
\hline In vitro & SGC7901 and BGC823 cells & $\begin{array}{l}5,10,25,50,100,200, \\
\text { and } 400 \mu \mathrm{M}\end{array}$ & $\begin{array}{l}\text { Inhibiting the invasion and migration of human gastric cancer cells by } \\
\text { blocking the MALAT1-mediated epithelial-to-mesenchymal transition }\end{array}$ & [73] \\
\hline \multicolumn{5}{|l|}{ Liver diseases } \\
\hline In vivo & Mice & $0.2 \%$ of diet & $\begin{array}{l}\text { Improving HFD-induced fatty liver by downregulating adipose } \\
\text { differentiation-related proteins and increasing the numbers of } \mathrm{CD} 68^{+} \text {Kupffer } \\
\text { cells }\end{array}$ & [9] \\
\hline In vivo & Rats & $10 \mathrm{mg} / \mathrm{kg}$ & $\begin{array}{l}\text { Attenuating hepatic fibrosis by restoring the architecture and normalizing } \\
\text { collagen deposition, mainly due to its antioxidative activities and } \\
\text { downregulation of } \alpha \text {-SMA }\end{array}$ & [80] \\
\hline In vivo & Rats & $50,100 \mathrm{mg} / \mathrm{kg}$ & Alleviating NAFLD by upregulating LDLR and SRB1 gene expressions & [83] \\
\hline In vivo & Rats & $250 \mathrm{mg} / \mathrm{kg} /$ day & Downregulating HIF- $1 \alpha$ expression and mitochondrial ROS production & [85] \\
\hline $\begin{array}{l}\text { In vitro; } \\
\text { In vivo }\end{array}$ & $\begin{array}{l}\text { HepG2 cells; } \\
\text { Mice }\end{array}$ & $\begin{array}{c}45 \mu \mathrm{mol} \\
10,30,100 \mathrm{mg} / \mathrm{kg}\end{array}$ & $\begin{array}{l}\text { Restoring the morphology and function of alcohol-injured liver through } \\
\text { inducing autophagy }\end{array}$ & [86] \\
\hline In vivo & Rats & $10 \mathrm{mg} / \mathrm{kg}$ & $\begin{array}{l}\text { Mitigating liver cirrhosis by improving the homing of bone marrow-derived } \\
\text { mesenchymal stem cells }\end{array}$ & [87] \\
\hline \multicolumn{5}{|l|}{ Diabetes } \\
\hline In vivo & Rats & $20 \mathrm{mg} / \mathrm{kg}$ & $\begin{array}{l}\text { Increasing insulin action and glucose utilization due to visfatin expression } \\
\text { restoration, SIRT1 activation, and glucose transporter modulation }\end{array}$ & [89] \\
\hline In vivo & Mice & $50 \mathrm{mg} / \mathrm{kg}$ & $\begin{array}{l}\text { Increasing glucose uptake to improve insulin resistance in the muscle by } \\
\text { decreasing DAG accumulation and PKC- } \theta \text { translocation, and preventing } \\
\text { lipolysis under the condition of adipose hypoxia }\end{array}$ & [90] \\
\hline In vivo & Rats & $147.6 \mathrm{mg} / \mathrm{kg} /$ day & Preventing the offspring's glucose intolerance and islet dysfunction & [91] \\
\hline In vivo & Mice & $0.3 \%$ diet & $\begin{array}{l}\text { Reducing blood glucose levels, plasma lipids, and free fatty acids, inhibiting } \\
\text { the expression of inflammatory mediators both in the aorta and in the blood, } \\
\text { by inhibiting the NF- } \mathrm{kB} \text { pathway }\end{array}$ & [92] \\
\hline
\end{tabular}


Table 2. Cont.

\begin{tabular}{|c|c|c|c|c|}
\hline Study Type & Subject & Dose & Main Findings & Ref. \\
\hline In vivo & Mice & $50 \mathrm{mg} / \mathrm{kg}$ & $\begin{array}{l}\text { Preventing ROS-mediated mitochondrial fission via AMPK-dependent } \\
\text { upregulation of Drp1 phosphorylation, and blocking the activation of NALP3 } \\
\text { inflammasome via inhibition of ERS }\end{array}$ & [93] \\
\hline In vivo & Zebrafish & $40 \mathrm{mg} / \mathrm{kg} /$ day & Inhibiting transcriptional regulators such as EP300 & [95] \\
\hline In vivo & Mice & $0.06 \%$ diet & $\begin{array}{l}\text { Decreasing the body weight and fat mass, reducing leptin and lipids in plasma, } \\
\text { modulating metabolism of glucose and insulin, and restoring immune } \\
\text { dysfunction by activating PI3K/SIRT1 and Nrf2 signaling pathway }\end{array}$ & [96] \\
\hline $\begin{array}{l}\text { In vitro; } \\
\text { In vivo }\end{array}$ & $\begin{array}{l}\text { 3T3-L1 cells; } \\
\quad \text { Mice }\end{array}$ & $\begin{array}{l}0.03 \text { to } 100 \mu \mathrm{M} \\
1,10,30 \mathrm{mg} / \mathrm{kg}\end{array}$ & $\begin{array}{l}\text { In vitro: low concentrations of resveratrol }(1-10 \mu \mathrm{M}) \text { suppressed adipogenic } \\
\text { differentiation in pre-adipocytes, downregulated the expression of PPAR- } \gamma \\
\text { and perilipin protein in differentiated adipocytes, and inhibiting } \\
\text { TNF- } \alpha \text {-induced lipolysis in mature adipocytes } \\
\text { In vivo: Dose-dependently decreasing weight gain and lipid deposition in the } \\
\text { liver and adipose tissue }\end{array}$ & [97] \\
\hline In vitro & RAW 264.7 macrophage cells & $25 \mu \mathrm{M}$ & $\begin{array}{l}\text { Enhancing the catecholamine production, accompanying by suppressing the } \\
\text { pro-inflammatory M1 macrophages, and activating anti-inflammatory M2 } \\
\text { macrophages in white adipose tissue }\end{array}$ & [98] \\
\hline $\begin{array}{l}\text { In vitro; } \\
\text { In vivo }\end{array}$ & $\begin{array}{l}\text { L6 myogenic cell line; } \\
\text { Rats }\end{array}$ & $\begin{array}{l}1,5,10,25 \text { or } 50 \mu \mathrm{M} \\
0.4 \% \text { diet }\end{array}$ & $\begin{array}{l}\text { In vitro: Improving mitochondrial function and reducing oxidative stress } \\
\text { through the PKA/LKB1/AMPK pathway; } \\
\text { In vivo: Preventing muscle loss and myofiber size decrease, improving grip } \\
\text { strength, and abolishing excessive fat accumulation }\end{array}$ & [100] \\
\hline In vivo & Mice & $0.06 \%$ diet & $\begin{array}{l}\text { Improving obesity-related complications by restoring plasma thyroid hormone } \\
\text { levels, and attenuating oxidative stress in the heart }\end{array}$ & [101] \\
\hline In vitro & Human sperm & $2.6,6,15,30,50,100 \mu \mathrm{mol} / \mathrm{L}$ & $\begin{array}{l}\text { Improving obesity-related complications by restoring reproductive } \\
\text { dysfunction like infertility }\end{array}$ & [102] \\
\hline \multicolumn{5}{|c|}{ Alzheimer's disease and Parkinson's disease } \\
\hline In vivo & Rats & $20 \mathrm{mg} / \mathrm{kg} /$ day & $\begin{array}{l}\text { Ameliorating ERS by downregulating the gene expression of CHOP and } \\
\text { GRP78, inhibiting caspase-3 activity, and ameliorating oxidative damage via } \\
\text { suppressing xanthine oxidase activity and protein carbonyl formation as well } \\
\text { as activating glutathione peroxidase and Nrf2 signaling pathway }\end{array}$ & [10] \\
\hline
\end{tabular}


Table 2. Cont.

\begin{tabular}{|c|c|c|c|c|}
\hline Study Type & Subject & Dose & Main Findings & Ref. \\
\hline In vitro & CL2006 cells & $100 \mu \mathrm{M}$ & $\begin{array}{l}\text { Inhibiting the aggregation of } A \beta \text { by modulating specific proteins such as } \\
\text { UBL/XBP-1 involved in proteostasis }\end{array}$ & [103] \\
\hline In vivo & Mice & $16 \mathrm{mg} / \mathrm{kg} /$ day & $\begin{array}{l}\text { Preventing memory loss by decreasing elevated levels of mitochondrial } \\
\text { complex IV protein in the mouse brain via the activation of SIRT1 and } \\
\text { AMPK pathways }\end{array}$ & [104] \\
\hline In vivo & Mice & $100 \mathrm{mg} / \mathrm{kg} /$ day & Preventing memory loss via the activation of SIRT1 and AMPK pathways & [105] \\
\hline $\begin{array}{l}\text { In vitro; } \\
\text { In vivo }\end{array}$ & $\begin{array}{l}\text { SH-SY5Y cells; } \\
\text { Mice }\end{array}$ & $\begin{array}{c}50 \mu \mathrm{M} ; \\
50 \mathrm{mg} / \mathrm{kg}\end{array}$ & $\begin{array}{l}\text { Elevating miR-214 expression, leading to decreased mRNA expression } \\
\text { of } \alpha \text {-synuclein }\end{array}$ & [106] \\
\hline \multicolumn{5}{|c|}{ Sex-dependent effects of resveratrol } \\
\hline In vivo & Rats & $2.5 \mathrm{mg} / \mathrm{kg} /$ day & $\begin{array}{l}\text { Superior improvements of MI in females in terms of IVSDs, ESV, EF, FS, and } \\
\text { IVRT, among which IVRT is purely sex-dependent }\end{array}$ & [109] \\
\hline In vivo & Rats & $50 \mathrm{mg} / \mathrm{L}$ in drinking water & $\begin{array}{l}\text { Increasing the relaxations to estrogen in aortae, more potent in males, } \\
\text { probably due to resveratrol's promoting nitric oxide and/or suppressing } \\
\text { superoxide effects }\end{array}$ & [110] \\
\hline $\begin{array}{l}\text { In vitro; } \\
\text { In vivo }\end{array}$ & MESC2.10 and SN4741 cells; Mice & $\begin{array}{l}20 \mathrm{mg} / \mathrm{kg} \\
10 \mu \mathrm{M}\end{array}$ & $\begin{array}{l}\text { Increasing DAT in the striatum in females but not in males; } \\
\text { Upregulating DAT in the dopaminergic cells by inducing its gene transcription }\end{array}$ & [111] \\
\hline In vivo & Mice & $100 \mathrm{mg} / \mathrm{kg}$ & $\begin{array}{l}\text { Adverse effects in females but not in males, regarding weight loss, stool } \\
\text { consistency, and discomfort }\end{array}$ & [112] \\
\hline
\end{tabular}

Abbreviations used in the table: AC, acetyl; AhR, aryl hydrocarbon receptor; Akt, protein Kinase B; AMPK, AMP-activated protein kinase; A $\beta$, amyloid $\beta$; $c$ AMP, cyclic adenosine monophosphate; CAT, catalase; cGMP, cyclic guanosine monophosphate; CHOP, C/EBP homologous protein; COX-2, cyclooxygenase-2; DAG, diacylglycerol; DAT, dopamine transporter; $\mathrm{EF}$, ejection fraction; EGFR, epidermal growth factor receptor; eNOS, endothelial nitric oxide synthase; ERK, extracellular signal-regulated kinases; ERR $\alpha$, estrogen related receptor $\alpha$; ERS, EF, ejection fraction; EGFR, epidermal growth factor receptor; eNOS, endothelial nitric oxide synthase; ERK, extracellular signal-regulated kinases; ERR $\alpha$, estrogen related receptor $\alpha$; ERS,
endoplasmic reticulum stress; Er $\alpha$, estrogen receptor $\alpha ; E R \alpha+$, estrogen receptor alpha positive; ESV, end systolic volume; EV71, enterovirus 71; FERM, band 4.1, ezrin, radixin, and moesin; endoplasmic reticulum stress; Er $\alpha$, estrogen receptor $\alpha$; ER $\alpha+$, estrogen receptor alpha positive; ESV, end systolic volume; EV71, enterovirus 71; FERM, band 4.1, ezrin, radixin, and moesin;
FoxO1, forkhead box protein O1; FS, fractional shortening; GPx, glutathione peroxidase; GRP78, glucose-regulated protein 78; G $\beta L$, G protein beta subunit-like; HFD, high-fat diet; HIF-1 $\alpha$, FoxO1, forkhead box protein O1; FS, fractional shortening; GPx, glutathione peroxidase; GRP78, glucose-regulated protein 78; G $\beta L$, G protein beta subunit-like; HFD, high-fat diet; HIF-1 $\alpha$,
hypoxia-inducible factor $1 \alpha$; HMGB1, high mobility group box 1; HMGB1, high mobility group box 1; HO-1, heme oxygenase (decycling) 1 ; HSL, hormone-sensitive lipase; ICAM-1, hypoxia-inducible factor $1 \alpha$; HMGB1, high mobility group box 1; HMGB1, high mobility group box 1; HO-1, heme oxygenase (decycling) 1 ; HSL, hormone-sensitive lipase; ICAM-1, intercellular adhesion molecule-1; IFN- $\gamma$, interferon $\gamma$; IKK, IKB kinase; IL-1 $\beta$, interleukin-1 $\beta$; IVRT, isovolumic relaxation time; IVSDs, interventricular septal wall dimension at systole;
I $B \alpha$, nuclear factor of kappa light polypeptide gene enhancer in B-cells inhibitor $\alpha$; JAK, Janus kinase; Keap1, Kelch-like ECH-associated protein 1; LDLR, low-density lipoprotein receptor; LKB1, liver kinase B1; LPS, lipopolysaccharides; MALAT1, metastasis-associated lung adenocarcinoma transcript 1; MAP2K, mitogen-activated protein kinase kinase; MAPK, mitogen-activated protein kinase; MCP-1, monocyte chemoattractant protein-1; MI, myocardial infarction; mSIN1, mammalian stress-activated protein kinase interacting protein 1; mTOR, mammalian target of rapamycin; mTORC2, mTOR Complex 2; NAD, nicotinamide adenine dinucleotide; NAFLD, non-alcoholic fatty liver disease; NALP3, NACHT, LRR, and PYD domains-containg phosphe 3-Kiase, PIP2, phe protein kinase $1 \alpha$; PLSCR1, phospholipid scramblase 1; PPAR- $\gamma$, peroxisome proliferator-activated receptor $\gamma$; PTEN, phosphatase and tensin homolog; RANTES, regulated on activation normal T cell expressed and secreted; RICTOR, the rapamycin-insensitive companion of mTOR; SARM, sterile $\alpha$ and armadillo motif protein; SIRT, sirtuin 1; $\alpha$-SMA, smooth muscle actin; SOD, superoxide dismutase; SRB1, scavenger receptor class B type I; STAT, signal transducer and activator of transcription; tBregs, tumor-evoked regulatory B cells; TF, transcription factor; TGF- $\beta$, transforming growth factor $\beta$; TLR4, toll-like receptor 4 ; TNF- $\alpha$, tumor necrosis factor $\alpha$; TRIF, toll/IL-1 receptor domain-containing adaptor inducing $\beta$ interferon; UBL, ubiquitin-like protein; XBP-1, X-box binding protein 1. 


\section{Clinical Trials}

In light of the positive epidemiological evidence and the promising results from experimental studies, resveratrol has been investigated in the human population as a potential nutraceutical (Table 3). There are certain encouraging outcomes reported. Specifically, resveratrol intake $(500 \mathrm{mg} /$ day for 30 days) was demonstrated to reduce CVD risk factors by increasing SIRT1, enhancing total antioxidant capacity in healthy individuals, decreasing low-density lipoprotein cholesterol (LDL-C), ApoB, and oxidized LDL [113-115]. Moreover, resveratrol prevented bone density loss (500 mg/day for 6 months) in type-2 diabetic patients [116]. In addition, resveratrol showed benefits in obesity, NAFLD, and neurodegenerative diseases $[15,16,117,118]$. However, some null outcomes have also been reported. For instance, resveratrol intake ( $250 \mathrm{mg} /$ day for 8 weeks) did not increase SIRT1 nor improve many cardiovascular risk factors in healthy aged men [58]. In some other studies, no significant improvements were found in metabolic biomarkers in patients with Alzheimer's disease, obesity or type-2 diabetes, respectively, though their resveratrol intake ranged from 150 to $1000 \mathrm{mg} /$ day with different duration of 4-52 weeks [119-122]. Therefore, the outcomes of clinical studies are not always consistent. Of note, the health effects of resveratrol as a therapeutic intervention may be affected by many factors, such as baseline health status of the subjects, their demographic profile, lifestyle, eating pattern, resveratrol dose, and intervention period. Nevertheless, a well-designed study, proper sample size, and a scientific evaluation system are also needed. Furthermore, although resveratrol is well-tolerated and safe as reported by most of the clinical trials, very few adverse effects (e.g., nausea and diarrhea) were observed, as well as some unfavorable results like an increase in total cholesterol, ApoB, the homeostatic model assessment-insulin resistance (HOMA-IR) score, fasting blood glucose, body fat, and the inflammatory markers $[15,114,118]$. Interestingly, resveratrol was reported to mask the exercise training-induced benefits, blunting the improved cardiovascular health parameters [58]. It might be attributable to the potent antioxidant capability of resveratrol, which could scavenge the free radicals induced by exercise training, because the appropriate number of free radicals is necessary for health maintenance. Therefore, it could be suggested that foods containing resveratrol should not be consumed during exercise. 
Table 3. The results of resveratrol from clinical research.

\begin{tabular}{|c|c|c|c|c|c|c|}
\hline Population & Targeting Diseases & Study Type & $\begin{array}{l}\text { Sample Size } \\
\text { (Valid Data) }\end{array}$ & $\begin{array}{l}\text { Resveratrol Dose } \\
\text { and Duration }\end{array}$ & $\begin{array}{c}\text { Main Findings: } \\
\text { Resveratrol vs. Measurements/Risk Factors/Biomarkers }\end{array}$ & Ref. \\
\hline $\begin{array}{l}\text { Healthy and slightly } \\
\text { overweight }\end{array}$ & CVD-atherosclerosis & Randomized, parallel & $\begin{array}{l}\mathrm{N}=48(\text { male, } 24 ; \\
\quad \text { female, } 24)\end{array}$ & $\begin{array}{l}\text { Resveratrol supplement, } \\
500 \mathrm{mg} / \text { day ( } 30 \text { days) }\end{array}$ & $\begin{array}{l}\text { Favorable: Increased serum SIRT1 concentrations from } 1.06 \pm 0.71 \text { to } \\
5.75 \pm 2.98 \text { ng/mL, } p<0.0001 \\
\text { Null: Did not influence the various metabolic parameters (BW, BMI, WC, HR, } \\
\text { BP, HDL, LDL, TG, BG, estradiol, estrone, insulin, hsCRP, and TAC) } \\
\text { Unfavorable: Increased TC, ApoB, and HOMA-IR score }\end{array}$ & [114] \\
\hline $\begin{array}{l}\text { Asymptomatic } \\
\text { hypercholesterolemics } \\
\text { (AHCs) and } \\
\text { normohypercholemics } \\
\text { (NC) }\end{array}$ & CVD—atherogenesis & $\begin{array}{l}\text { Randomized, } \\
\text { placebo-controlled }\end{array}$ & $\begin{array}{l}\mathrm{N}=40(\text { male, } 21 \\
\quad \text { female, } 19)\end{array}$ & $\begin{array}{l}\text { Resveratrol supplement, } \\
150 \mathrm{mg} / \text { day (4 weeks) }\end{array}$ & $\begin{array}{l}\text { Favorable: } \text { Increased TAC (mean value increased to } 136.7 \% \text { after } \\
\text { consumption, } p=0.035 \text { ) in healthy NC individuals and facilitated an increase } \\
\text { in vitamin E (7.18 umol/l, i.e., } 35.72 \% \text { ) in AHC } \\
\text { Null: No differences found in TC, TG, HDL, LDL, TAC (in AHC), } \\
\text { and vitamin E (in NC) }\end{array}$ & [113] \\
\hline $\begin{array}{l}\text { Overweight and slightly } \\
\text { obese volunteers }\end{array}$ & $\begin{array}{l}\text { CVD_endothelial } \\
\text { function }\end{array}$ & $\begin{array}{l}\text { Randomized, } \\
\text { double-blind, } \\
\text { placebo-controlled }\end{array}$ & $\begin{array}{l}\mathrm{N}=45(\text { male, } 25 ; \\
\quad \text { female, 20) }\end{array}$ & $\begin{array}{l}\text { Trans-resveratrol } \\
\text { supplement, } 150 \mathrm{mg} / \mathrm{day} \\
\text { (4 weeks) }\end{array}$ & $\begin{array}{l}\text { Null: Did not improve endothelial function (FMD, arterial stiffness, and other } \\
\text { endothelial activation markers), inflammation (IL-6 and TNF- } \alpha \text { ), glucose and } \\
\text { lipid metabolism (BG, insulin, and serum TG) }\end{array}$ & [122] \\
\hline $\begin{array}{l}65 \text { years or older with } \\
\text { peripheral artery disease } \\
\text { (PAD) }\end{array}$ & CVD-PAD & $\begin{array}{l}\text { Randomized, } \\
\text { double-blind, } \\
\text { placebo-controlled }\end{array}$ & $\begin{array}{l}\mathrm{N}=66(\text { male, } 45 ; \\
\quad \text { female, 21) }\end{array}$ & $\begin{array}{l}\text { Trans-resveratrol } \\
\text { supplement, } 125 \text { and } \\
500 \mathrm{mg} / \text { day (6 months) }\end{array}$ & $\begin{array}{l}\text { Favorable: } 125 \mathrm{mg} / \text { day improved the outcome of 6-min walk test results } \\
\text { statistically significant (95\% CI: }-5.7 \text { to } 39.5) \text { but not clinically meaningful } \\
\text { Null: } 500 \mathrm{mg} / \text { day showed no significant improvement }\end{array}$ & [123] \\
\hline $\begin{array}{l}\text { Patients in primary } \\
\text { cardiovascular disease } \\
\text { prevention }\end{array}$ & CVD-atherogenesis & $\begin{array}{l}\text { Triple-blind, } \\
\text { randomized, } \\
\text { placebo-controlled }\end{array}$ & $\begin{array}{l}\mathrm{N}=75(\text { male, } 34 \\
\quad \text { female, } 41)\end{array}$ & $\begin{array}{l}\text { Resveratrol-enriched } \\
\text { grape extract, } 350 \mathrm{mg} / \text { day } \\
\text { (6 months) }\end{array}$ & $\begin{array}{l}\text { Favorable: } \text { Decreased LDL-C }(-4.5 \%, p=0.04), \mathrm{ApoB}(-9.8 \%, p=0.014), \\
\text { oxidized LDL }(-20 \%, p=0.001), \text { and oxidized LDL/ApoB }(-12.5 \%, p=0.000) \text {; } \\
\text { increased ratio non-HDL-C/ApoB }(8.5 \%, p=0.046) \\
\text { Null: } \text { No clinically significant effects on hepatic, thyroid, and renal function } \\
\text { (GGT, AST, ALP, bilirubin and albumin; TSH, T4; CPK, creatinine, and urate) }\end{array}$ & [115] \\
\hline Healthy aged men & CVD & $\begin{array}{l}\text { Randomized, } \\
\text { double-blind, } \\
\text { placebo-controlled }\end{array}$ & $\mathrm{N}=27$ (male) & $\begin{array}{l}\text { Trans-resveratrol } \\
\text { supplement, } \\
250 \mathrm{mg} / \text { day }(8 \text { weeks })\end{array}$ & $\begin{array}{l}\text { Null: No effects on SIRT1 protein concentrations or cardiovascular parameters } \\
\text { (BG, TC, and HDL), and VCAM-1 } \\
\text { Unfavorable: Abolished the exercise training-induced improvement in } \\
\text { maximal oxygen uptake, BP, and lipids (LDL, TC/HDL ratio, and TG) }\end{array}$ & {$[58]$} \\
\hline $\begin{array}{l}\text { Women at increased breast } \\
\text { cancer risk }\end{array}$ & Cancer-breast cancer & $\begin{array}{c}\text { Randomized, } \\
\text { double-blind, } \\
\text { placebo-controlled }\end{array}$ & $\mathrm{N}=39$ (male) & $\begin{array}{l}\text { Trans-resveratrol } \\
\text { supplement, } 10 \text { or } \\
100 \mathrm{mg} / \text { day (12 weeks) }\end{array}$ & $\begin{array}{l}\text { Favorable: Decreased the methylation of RASSF- } 1 \alpha(p=0.047) \\
\text { Null: Did not significantly alter PGE2 }\end{array}$ & [124] \\
\hline $\begin{array}{l}\text { Patients with } \\
\text { type-2 diabetes }\end{array}$ & Type 2 diabetes & $\begin{array}{l}\text { Randomized, } \\
\text { double-blind, } \\
\text { placebo-controlled }\end{array}$ & $\begin{array}{l}\mathrm{N}=192(\text { male, } 126 ; \\
\quad \text { female, } 66)\end{array}$ & $\begin{array}{l}\text { Resveratrol supplement, } \\
40 \text { and } 500 \mathrm{mg} / \text { day } \\
\text { (6 months) }\end{array}$ & $\begin{array}{l}\text { Favorable: Prevented bone density loss }(500 \mathrm{mg} / \mathrm{d}) \text { (whole-body BMD }(0.01 \\
\left.\left.\text { vs. }-0.03 \mathrm{~g} / \mathrm{cm}^{2}, p=0.001\right), \text { whole-body BMC (4.04 vs. }-58.8 \mathrm{~g}, p<0.001\right), \\
\text { whole-body T-score }(0.15 \text { vs. }-0.26) \text {, and serum phosphorus }(0.07 \mathrm{vs.} \\
-0.01 \mu \mathrm{mol} / \mathrm{L}, p=0.002)) \text {; decreased CRP (not significantly) } \\
\text { Null: BW, BMI, WC, BP, FBG, HbA1c, insulin, HOMA-IR, C-peptide, FFAs, } \\
\text { ALT, AST, GGT, uric acid, IL-6, and adiponectin } \\
\text { Unfavorable: Slightly increased TC and TG }(500 \mathrm{mg} / \mathrm{d})\end{array}$ & [116] \\
\hline $\begin{array}{l}\text { Patients with } \\
\text { diet-controlled } \\
\text { type-2 diabetes }\end{array}$ & Type 2 diabetes & $\begin{array}{l}\text { Randomized, } \\
\text { double-blind, } \\
\text { placebo-controlled }\end{array}$ & $\mathrm{N}=14$ (male) & $\begin{array}{l}\text { Resveratrol capsules, } \\
1000 \mathrm{mg} / \text { day (5 weeks) }\end{array}$ & $\begin{array}{l}\text { Favorable: Modestly decreased FBG and HbA1c } \\
\text { Null: No significant effects on GLP-1 secretion, gastric emptying, glycemic } \\
\text { control (HbA1c, BG), energy intake, and BW }\end{array}$ & [121] \\
\hline
\end{tabular}


Table 3. Cont

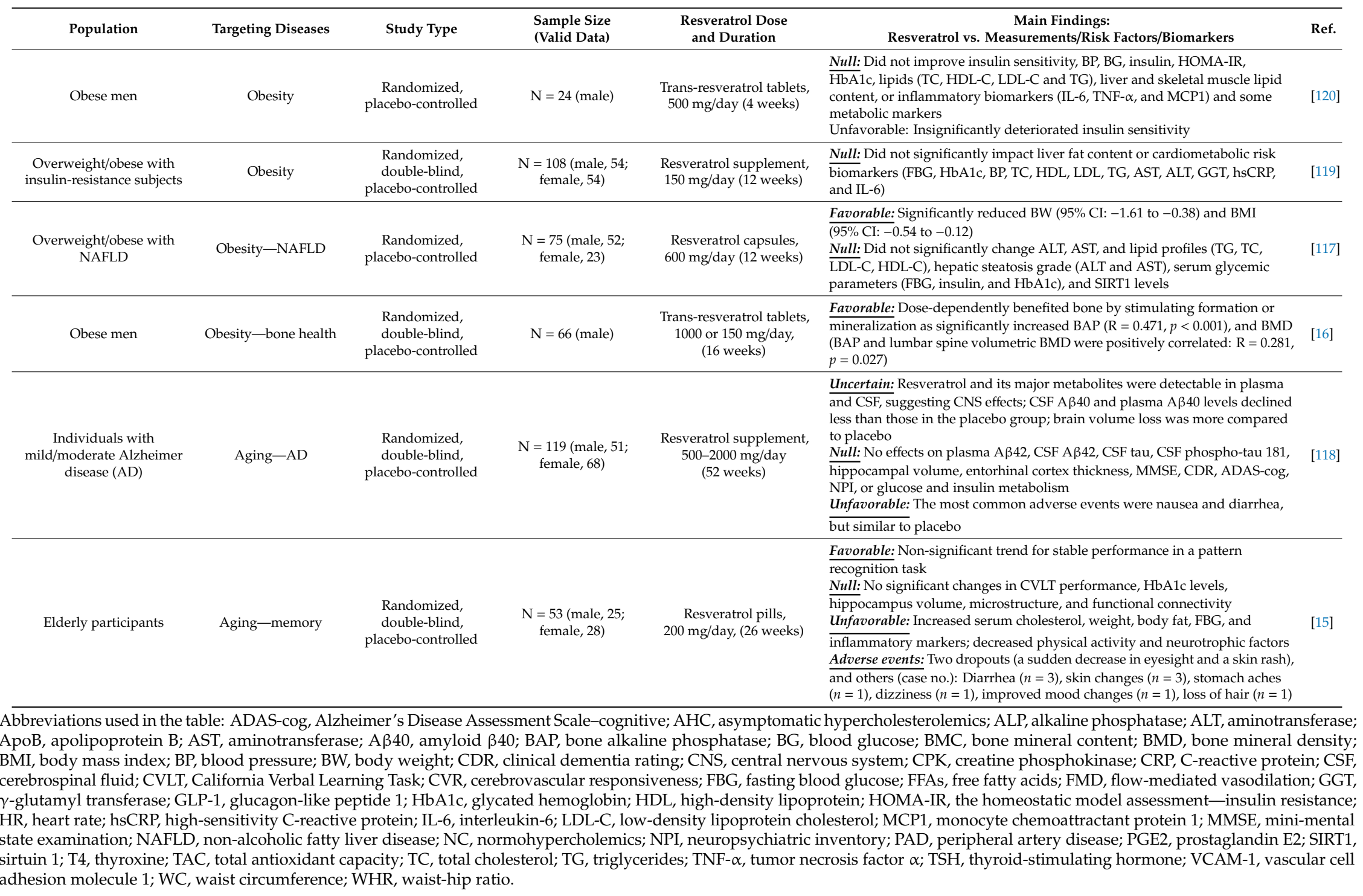




\section{Conclusions}

Resveratrol is one of the most investigated bioactive compounds in foods. A number of epidemiologic studies have demonstrated that resveratrol is effective in the prevention of some diseases such as CVDs and cancer, although the results are sometimes inconsistent. In addition, the experimental studies have shown that resveratrol possesses many bioactivities and health benefits like antioxidant, anti-inflammatory, immunomodulatory effects, and improving CVDs, cancer, liver diseases, diabetes, obesity, Alzheimer's disease, and Parkinson's disease. Furthermore, resveratrol showed some effects in patients with CVDs and obesity in clinical trials, although inconsistency has also been reported. In the future, more bioactivities and health benefits of resveratrol should be evaluated, and further clarification of the underlying mechanisms of action is required. In order to develop resveratrol into functional foods and pharmaceuticals, more clinical trials are essential to confirm its efficacy and observe the possible adverse events, and the dose-effect relationship should be paid special attention as well.

Author Contributions: Conceptualization, X.M., R.-Y.G., and H.-B.L.; Writing-original draft preparation, X.M. and J.Z.; Writing-review and editing, C.-N.Z., R.-Y.G., and H.-B.L.; supervision, R.-Y.G. and H.-B.L.; funding acquisition, R.-Y.G., and H.-B.L. All authors have read and agreed to the published version of the manuscript.

Funding: This research was funded by China Central Public-interest Scientific Institution Basal Research Fund (Grant No. Y2020XK05), the National Key R\&D Program of China (Grant No. 2018YFC1604400), and the Key Project of Guangdong Provincial Science and Technology Program (Grant No. 2014B020205002).

Conflicts of Interest: The authors declare no conflict of interest.

\section{References}

1. Meng, X.; Li, Y.; Li, S.; Zhou, Y.; Gan, R.-Y.; Xu, D.-P.; Li, H.-B. Dietary sources and bioactivities of melatonin. Nutrients 2017, 9, 367. [CrossRef] [PubMed]

2. Zhao, C.-N.; Meng, X.; Li, Y.; Li, S.; Liu, Q.; Tang, G.-Y.; Li, H.-B. Fruits for prevention and treatment of cardiovascular diseases. Nutrients 2017, 9, 598. [CrossRef] [PubMed]

3. Weiskirchen, S.; Weiskirchen, R. Resveratrol: How much wine do you have to drink to stay healthy? Adv. Nutr. 2016, 7, 706-718. [CrossRef] [PubMed]

4. Jang, M.; Cai, L.; Udeani, G.O.; Slowing, K.V.; Thomas, C.F.; Beecher, C.W.; Fong, H.H.; Farnsworth, N.R.; Kinghorn, A.D.; Mehta, R.G.; et al. Cancer chemopreventive activity of resveratrol, a natural product derived from grapes. Science 1997, 275, 218-220. [CrossRef] [PubMed]

5. Lin, Y.; Yngve, A.; Lagergren, J.; Lu, Y. A dietary pattern rich in lignans, quercetin and resveratrol decreases the risk of oesophageal cancer. Br. J. Nutr. 2014, 112, 2002-2009. [CrossRef] [PubMed]

6. Zamora-Ros, R.; Urpi-Sarda, M.; Lamuela-Raventós, R.M.; Martínez-González, M.Á.; Salas-Salvadó, J.; Arós, F.; Fitó, M.; Lapetra, J.; Estruch, R.; Andres-Lacueva, C. High urinary levels of resveratrol metabolites are associated with a reduction in the prevalence of cardiovascular risk factors in high-risk patients. Pharmacol. Res. 2012, 65, 615-620. [CrossRef]

7. Mattison, J.A.; Wang, M.; Bernier, M.; Zhang, J.; Park, S.; Maudsley, S.; An, S.S.; Santhanam, L.; Martin, B.; Faulkner, S.; et al. Resveratrol prevents high fat/sucrose diet-induced central arterial wall inflammation and stiffening in nonhuman primates. Cell Metab. 2014, 20, 183-190. [CrossRef]

8. Chong, E.; Chang, S.; Hsiao, Y.; Singhal, R.; Liu, S.; Leha, T.; Lin, W.; Hsu, C.; Chen, Y.; Chen, Y.; et al. Resveratrol, a red wine antioxidant, reduces atrial fibrillation susceptibility in the failing heart by PI3K/AKT/eNOS signaling pathway activation. Heart Rhythm 2015, 12, 1046-1056. [CrossRef]

9. Nishikawa, K.; Iwaya, K.; Kinoshita, M.; Fujiwara, Y.; Akao, M.; Sonoda, M.; Thiruppathi, S.; Suzuki, T.; Hiroi, S.; Seki, S.; et al. Resveratrol increases CD68 ${ }^{+}$Kupffer cells colocalized with adipose differentiation-related protein and ameliorates high-fat-diet-induced fatty liver in mice. Mol. Nutr. Food Res. 2015, 59, 1155-1170. [CrossRef]

10. Gaballah, H.H.; Zakaria, S.S.; Elbatsh, M.M.; Tahoon, N.M. Modulatory effects of resveratrol on endoplasmic reticulum stress-associated apoptosis and oxido-inflammatory markers in a rat model of rotenone-induced Parkinson's disease. Chem. Biol. Interact. 2016, 251, 10-16. [CrossRef] 
11. Wu, H.; Sheng, Z.; Xie, J.; Li, R.; Chen, L.; Li, G.; Wang, L.; Xu, B. Reduced HMGB 1-mediated pathway and oxidative stress in resveratrol-treated diabetic mice: A possible mechanism of cardioprotection of resveratrol in diabetes mellitus. Oxid. Med. Cell. Longev. 2016, 2016. [CrossRef] [PubMed]

12. Moussa, C.; Hebron, M.; Huang, X.; Ahn, J.; Rissman, R.A.; Aisen, P.S.; Turner, R.S. Resveratrol regulates neuro-inflammation and induces adaptive immunity in Alzheimer's disease. J. Neuroinflamm. 2017, $14,1$. [CrossRef] [PubMed]

13. Sung, M.M.; Kim, T.T.; Denou, E.; Soltys, C.M.; Hamza, S.M.; Byrne, N.J.; Masson, G.; Park, H.; Wishart, D.S.; Madsen, K.L.; et al. Improved glucose homeostasis in obese mice treated with resveratrol is associated with alterations in the gut microbiome. Diabetes 2017, 66, 418-425. [CrossRef] [PubMed]

14. Cheng, T.M.; Chin, Y.T.; Ho, Y.; Chen, Y.R.; Yang, Y.N.; Yang, Y.C.; Shih, Y.J.; Lin, T.I.; Lin, H.Y.; Davis, P.J. Resveratrol induces sumoylated COX-2-dependent anti-proliferation in human prostate cancer LNCaP cells. Food Chem. Toxicol. 2018, 112, 67-75. [CrossRef] [PubMed]

15. Huhn, S.; Beyer, F.; Zhang, R.; Lampe, L.; Grothe, J.; Kratzsch, J.; Willenberg, A.; Breitfeld, J.; Kovacs, P.; Stumvoll, M.; et al. Effects of resveratrol on memory performance, hippocampus connectivity and microstructure in older adults-A randomized controlled trial. Neuroimage 2018, 174, 177-190. [CrossRef] [PubMed]

16. Ornstrup, M.J.; Harslof, T.; Kjaer, T.N.; Langdahl, B.L.; Pedersen, S.B. Resveratrol increases bone mineral density and bone alkaline phosphatase in obese men: A randomized placebo-controlled trial. J. Clin. Endocr. Metab. 2014, 99, 4720-4729. [CrossRef]

17. Levi, F.; Pasche, C.; Lucchini, F.; Ghidoni, R.; Ferraroni, M.; La Vecchia, C. Resveratrol and breast cancer risk. Eur. J. Cancer Prev. 2005, 14, 139-142. [CrossRef]

18. Rabassa, M.; Zamora-Ros, R.; Urpi-Sarda, M.; Bandinelli, S.; Ferrucci, L.; Andres-Lacueva, C.; Cherubini, A. Association of habitual dietary resveratrol exposure with the development of frailty in older age: The Invecchiare in Chianti study. Am. J. Clin. Nutr. 2015, 102, 1534-1542. [CrossRef]

19. Sohrab, G.; Hosseinpour-Niazi, S.; Hejazi, J.; Yuzbashian, E.; Mirmiran, P.; Azizi, F. Dietary polyphenols and metabolic syndrome among Iranian adults. Int. J. Food Sci. Nutr. 2013, 64, 661-667. [CrossRef]

20. Renaud, S.; de Lorgeril, M. Wine, alcohol, platelets, and the French paradox for coronary heart disease. Lancet 1992, 339, 1523-1526. [CrossRef]

21. Tresserra-Rimbau, A.; Rimm, E.B.; Medina-Remon, A.; Martinez-Gonzalez, M.A.; de la Torre, R.; Corella, D.; Salas-Salvado, J.; Gomez-Gracia, E.; Lapetra, J.; Aros, F.; et al. Inverse association between habitual polyphenol intake and incidence of cardiovascular events in the PREDIMED study. Nutr. Metab. Carbiovasc. Dis. 2014, 24, 639-647. [CrossRef] [PubMed]

22. Tresserra-Rimbau, A.; Rimm, E.B.; Medina-Remon, A.; Martinez-Gonzalez, M.A.; Lopez-Sabater, M.C.; Covas, M.I.; Corella, D.; Salas-Salvado, J.; Gomez-Gracia, E.; Lapetra, J.; et al. Polyphenol intake and mortality risk: A re-analysis of the PREDIMED trial. BMC Med. 2014, 12, 77. [CrossRef] [PubMed]

23. Li, G.P.; Zhu, Y.P.; Zhang, Y.P.; Lang, J.M.; Chen, Y.P.; Ling, W.P. Estimated daily flavonoid and stilbene intake from fruits, vegetables, and nuts and associations with lipid profiles in Chinese adults. J. Acad. Nutr. Diet. 2013, 113, 786-794. [CrossRef] [PubMed]

24. Pan, Y.; Zhang, H.; Zheng, Y.; Zhou, J.; Yuan, J.; Yu, Y.; Wang, J. Resveratrol exerts antioxidant effects by activating SIRT2 to deacetylate Prx1. Biochemistry US 2017, 56, 6325-6328. [CrossRef] [PubMed]

25. Yun, H.; Park, S.; Kim, M.; Yang, W.K.; Im, D.U.; Yang, K.R.; Hong, J.; Choe, W.; Kang, I.; Kim, S.S.; et al. AMP-activated protein kinase mediates the antioxidant effects of resveratrol through regulation of the transcription factor FoxO1. FEBS J. 2014, 281, 4421-4438. [CrossRef] [PubMed]

26. Ingles, M.; Gambini, J.; Miguel, M.G.; Bonet-Costa, V.; Abdelaziz, K.M.; El Alami, M.; Vina, J.; Borras, C. PTEN mediates the antioxidant effect of resveratrol at nutritionally relevant concentrations. Biomed. Res. Int. 2014, 580852. [CrossRef]

27. Singh, A.K.; Vinayak, M. Resveratrol alleviates inflammatory hyperalgesia by modulation of reactive oxygen species (ROS), antioxidant enzymes and ERK activation. Inflamm. Res. 2017, 66, 911-921. [CrossRef]

28. Fu, S.; Lv, R.; Wang, L.; Hou, H.; Liu, H.; Shao, S. Resveratrol, an antioxidant, protects spinal cord injury in rats by suppressing MAPK pathway. Saudi J. Biol. Sci. 2018, 25, 259-266. [CrossRef]

29. Li, J.; Feng, L.; Xing, Y.; Wang, Y.; Du, L.; Xu, C.; Cao, J.; Wang, Q.; Fan, S.; Liu, Q.; et al. Radioprotective and antioxidant effect of resveratrol in hippocampus by activating Sirt1. Int. J. Mol. Sci. 2014, 15, 5928-5939. [CrossRef] 
30. Li, S.; Zlia, G.; Chen, L.; Ding, Y.; Lian, J.; Hong, G.; Lu, Z. Resveratrol protects mice from paraquat-induced lung injury: The important role of SIRT1 and NRF2 antioxidant pathways. Mol. Med. Rep. 2016, 13, 1833-1838. [CrossRef]

31. Meng, Q.; Guo, T.; Li, G.; Sun, S.; He, S.; Cheng, B.; Shi, B.; Shan, A. Dietary resveratrol improves antioxidant status of sows and piglets and regulates antioxidant gene expression in placenta by Keap1-Nrf2 pathway and Sirt1. J. Anim. Sci. Biotechnol. 2018, 9, 34. [CrossRef] [PubMed]

32. Zhou, X.; Yang, J.; Zhou, M.; Zhang, Y.; Liu, Y.; Hou, P.; Zeng, X.; Yi, L.; Mi, M. Resveratrol attenuates endothelial oxidative injury by inducing autophagy via the activation of transcription factor EB. Nutr. Metab. 2019, 16, 42. [CrossRef] [PubMed]

33. Kim, J.; Kundu, M.; Viollet, B.; Guan, K. AMPK and mTOR regulate autophagy through direct phosphorylation of Ulk1. Nat. Cell Biol. 2011, 13, 132-141. [CrossRef] [PubMed]

34. Yang, S.J.; Lim, Y. Resveratrol ameliorates hepatic metaflammation and inhibits NLRP3 inflammasome activation. Metabolism 2014, 63, 693-701. [CrossRef] [PubMed]

35. Misawa, T.; Saitoh, T.; Kozaki, T.; Park, S.; Takahama, M.; Akira, S. Resveratrol inhibits the acetylated alphatubulin-mediated assembly of the NLRP3-inflammasome. Int. Immunol. 2015, 27, 425-434. [CrossRef] [PubMed]

36. Andrews, C.S.; Matsuyama, S.; Lee, B.; Li, J. Resveratrol suppresses NTHi-induced inflammation via upregulation of the negative regulator MyD88 short. Sci. Rep. 2016, 6, 34445. [CrossRef] [PubMed]

37. Chen, Y.H.; Fu, Y.C.; Wu, M.J. Does resveratrol play a role in decreasing the inflammation associated with contrast induced nephropathy in rat model? J. Clin. Med. 2019, 8, 147. [CrossRef]

38. Son, Y.; Chung, H.; Pae, H. Differential effects of resveratrol and its natural analogs, piceatannol and 3,5,4'-trans-trimethoxystilbene, on anti-inflammatory heme oxigenase-1 expression in RAW264.7 macrophages. Biofactors 2014, 40, 138-145. [CrossRef]

39. Nwachukwu, J.C.; Srinivasan, S.; Bruno, N.E.; Parent, A.A.; Hughes, T.S.; Pollock, J.A.; Gjyshi, O.; Cavett, V.; Nowak, J.; Garcia-Ordonez, R.D.; et al. Resveratrol modulates the inflammatory response via an estrogen receptor-signal integration network. ELife 2014, 3, e2057. [CrossRef]

40. Sadeghi, A.; Ebrahimi, S.S.S.; Golestani, A.; Meshkani, R. Resveratrol ameliorates palmitate-induced inflammation in skeletal muscle cells by attenuating oxidative stress and JNK/NF-KB pathway in a SIRT1-independent mechanism. J. Cell. Biochem. 2017, 118, 2654-2663. [CrossRef]

41. Ma, C.; Wang, Y.; Dong, L.; Li, M.; Cai, W. Anti-inflammatory effect of resveratrol through the suppression of NF-kB and JAK/STAT signaling pathways. Acta Bioch. Bioph. Sin. 2015, 47, 207-213. [CrossRef] [PubMed]

42. Pinheiro, D.; de Oliveira, A.; Coutinho, L.G.; Fontes, F.L.; de Medeiros, O.R.; Oliveira, T.T.; Faustino, A.; Lira, D.S.V.; de Melo, C.J.; Lajus, T.; et al. Resveratrol decreases the expression of genes involved in inflammation through transcriptional regulation. Free Radic. Biol. Med. 2019, 130, 8-22. [CrossRef] [PubMed]

43. Li, J.; Li, L.; Wang, S.; Zhang, C.; Zheng, L.; Jia, Y.; Xu, M.; Zhu, T.; Zhang, Y.; Rong, R. Resveratrol alleviates inflammatory responses and oxidative stress in rat kidney ischemia-reperfusion injury and $\mathrm{H}_{2} \mathrm{O}_{2}$-induced NRK-52E Cells via the Nrf2/TLR4/NF-kB Pathway. Cell. Physiol. Biochem. 2018, 45, 1677-1689. [CrossRef] [PubMed]

44. Wang, G.; Hu, Z.; Fu, Q.; Song, X.; Cui, Q.; Jia, R.; Zou, Y.; He, C.; Li, L.; Yin, Z. Resveratrol mitigates lipopolysaccharide-mediated acute inflammation in rats by inhibiting the TLR4/NF- kBp65/MAPKs signaling cascade. Sci. Rep. 2017, 7, 45006. [CrossRef] [PubMed]

45. Limagne, E.; Lancon, A.; Delmas, D.; Cherkaoui-Malki, M.; Latruffe, N. Resveratrol interferes with IL1 $\beta$-induced pro-inflammatory paracrine interaction between primary chondrocytes and macrophages. Nutrients 2016, 8, 280. [CrossRef] [PubMed]

46. Euba, B.; Lopez-Lopez, N.; Rodriguez-Arce, I.; Fernandez-Calvet, A.; Barberan, M.; Caturla, N.; Marti, S.; Diez-Martinez, R.; Garmendia, J. Resveratrol therapeutics combines both antimicrobial and immunomodulatory properties against respiratory infection by nontypeable Haemophilus influenzae. Sci. Rep. 2017, 7, 12860. [CrossRef]

47. Mastromarino, P.; Capobianco, D.; Cannata, F.; Nardis, C.; Mattia, E.; De Leo, A.; Restignoli, R.; Francioso, A.; Mosca, L. Resveratrol inhibits rhinovirus replication and expression of inflammatory mediators in nasal epithelia. Antivir. Res. 2015, 123, 15-21. [CrossRef]

48. Zhang, L.; Li, Y.; Gu, Z.; Wang, Y.; Shi, M.; Ji, Y.; Sun, J.; Xu, X.; Zhang, L.; Jiang, J.; et al. Resveratrol inhibits enterovirus 71 replication and pro-inflammatory cytokine secretion in rhabdosarcoma cells through blocking IKKs/NF-kB signaling pathway. PLoS ONE 2015, 10, e1168792. [CrossRef] 
49. Zhang, C.; Tian, Y.; Yan, F.; Kang, X.; Han, R.; Sun, G.; Zhang, H. Modulation of growth and immunity by dietary supplementation with resveratrol in young chickens receiving conventional vaccinations. Am. J. Vet. Res. 2014, 75, 752-759. [CrossRef]

50. Liu, T.; Zang, N.; Zhou, N.; Li, W.; Xie, X.; Deng, Y.; Ren, L.; Long, X.; Li, S.; Zhou, L.; et al. Resveratrol inhibits the TRIF-dependent pathway by upregulating sterile $\alpha$ and armadillo motif protein, contributing to anti-inflammatory effects after respiratory syncytial virus infection. J. Virol. 2014, 88, 4229-4236. [CrossRef]

51. Cui, Q.; Fu, Q.; Zhao, X.; Song, X.; Yu, J.; Yang, Y.; Sun, K.; Bai, L.; Tian, Y.; Chen, S.; et al. Protective effects and immunomodulation on piglets infected with rotavirus following resveratrol supplementation. PLOS ONE 2018, 13, e1926922. [CrossRef] [PubMed]

52. Smith, N.C.; Christian, S.L.; Taylor, R.G.; Santander, J.; Rise, M.L. Immune modulatory properties of 6-gingerol and resveratrol in Atlantic salmon macrophages. Mol. Immunol. 2018, 95, 10-19. [CrossRef] [PubMed]

53. Huang, T.; Chen, C.; Liu, H.; Lee, T.; Shieh, S. Resveratrol pretreatment attenuates concanavalin A-induced hepatitis through reverse of aberration in the immune response and regenerative capacity in aged mice. Sci. Rep. 2017, 7, 2705. [CrossRef] [PubMed]

54. Lai, X.; Pei, Q.; Song, X.; Zhou, X.; Yin, Z.; Jia, R.; Zou, Y.; Li, L.; Yue, G.; Liang, X.; et al. The enhancement of immune function and activation of NF- $\mathrm{kB}$ by resveratrol-treatment in immunosuppressive mice. Int. Immunopharmacol. 2016, 33, 42-47. [CrossRef]

55. Warburton, A.; Vasieva, O.; Quinn, P.; Stewart, J.P.; Quinn, J.P. Statistical analysis of human microarray data shows that dietary intervention with n-3 fatty acids, flavonoids and resveratrol enriches for immune response and disease pathways. Br. J. Nutr. 2018, 119, 239-249. [CrossRef]

56. Guo, N.H.; Fu, X.; Zi, F.M.; Song, Y.; Wang, S.; Cheng, J. The potential therapeutic benefit of resveratrol on Th17/Treg imbalance in immune thrombocytopenic purpura. Int. Immunopharmacol. 2019, 73, 181-192. [CrossRef]

57. Buttari, B.; Profumo, E.; Segoni, L.; D’Arcangelo, D.; Rossi, S.; Facchiano, F.; Saso, L.; Businaro, R.; Iuliano, L.; Rigano, R. Resveratrol counteracts inflammation in human M1 and M2 macrophages upon challenge with 7-oxo-cholesterol: Potential therapeutic implications in atherosclerosis. Oxid. Med. Cell. Longev. 2014, 257543. [CrossRef]

58. Gliemann, L.; Schmidt, J.F.; Olesen, J.; Bienso, R.S.; Peronard, S.L.; Grandjean, S.U.; Mortensen, S.P.; Nyberg, M.; Bangsbo, J.; Pilegaard, H.; et al. Resveratrol blunts the positive effects of exercise training on cardiovascular health in aged men. J. Physiol. 2013, 591, 5047-5059. [CrossRef]

59. Vasamsetti, S.B.; Karnewar, S.; Gopoju, R.; Gollavilli, P.N.; Narra, S.R.; Kumar, J.M.; Kotamraju, S. Resveratrol attenuates monocyte-to-macrophage differentiation and associated inflammation via modulation of intracellular GSH homeostasis: Relevance in atherosclerosis. Free Radic. Biol. Med. 2016, 96, 392-405. [CrossRef]

60. Javkhedkar, A.A.; Quiroz, Y.; Rodriguez-Iturbe, B.; Vaziri, N.D.; Lokhandwala, M.F.; Banday, A.A. Resveratrol restored Nrf2 function, reduced renal inflammation, and mitigated hypertension in spontaneously hypertensive rats. Am. J. Physiol. Reg. I. 2015, 308, R840-R846. [CrossRef]

61. Prysyazhna, O.; Wolhuter, K.; Switzer, C.; Santos, C.; Yang, X.; Lynham, S.; Shah, A.M.; Eaton, P.; Burgoyne, J.R. Blood pressure-lowering by the antioxidant resveratrol is counterintuitively mediated by oxidation of cGMP-dependent protein kinase. Circulation 2019, 140, 126-137. [CrossRef] [PubMed]

62. Deng, Z.Y.; Hu, M.M.; Xin, Y.F.; Gang, C. Resveratrol alleviates vascular inflammatory injury by inhibiting inflammasome activation in rats with hypercholesterolemia and vitamin $\mathrm{D}_{2}$ treatment. Inflamm. Res. 2015, 64, 321-332. [CrossRef] [PubMed]

63. Seo, Y.; Park, J.; Choi, W.; Ju Son, D.; Sung Kim, Y.; Kim, M.; Yoon, B.; Pyee, J.; Tae Hong, J.; Go, Y.; et al. Antiatherogenic effect of resveratrol attributed to decreased expression of ICAM-1 (intercellular adhesion molecule-1). Arterioscler. Thromb. Vasc. Biol. 2019, 39, 675-684. [CrossRef] [PubMed]

64. Fernandez-Castillejo, S.; Macia, A.; Motilva, M.J.; Catalan, U.; Sola, R. Endothelial cells deconjugate resveratrol metabolites to free resveratrol: A possible role in tissue factor modulation. Mol. Nutr. Food Res. 2019, 63, e1800715. [CrossRef]

65. Dillenburg, D.R.; Mostarda, C.; Moraes-Silva, I.C.; Ferreira, D.; Goncalves Bos, D.D.S.; Machado Duarte, A.A.; Irigoyen, M.C.; Rigatto, K. Resveratrol and grape juice differentially ameliorate cardiovascular autonomic modulation in L-NAME-treated rats. Auton. Neurosci. Basic 2013, 179, 9-13. [CrossRef] 
66. Tellone, E.; De Rosa, M.C.; Pirolli, D.; Russo, A.; Giardina, B.; Galtieri, A.; Ficarra, S. Molecular interactions of hemoglobin with resveratrol: Potential protective antioxidant role and metabolic adaptations of the erythrocyte. Biol. Chem. 2014, 395, 347-354. [CrossRef]

67. Lee-Chang, C.; Bodogai, M.; Martin-Montalvo, A.; Wejksza, K.; Sanghvi, M.; Moaddel, R.; de Cabo, R.; Biragyn, A. Inhibition of breast cancer metastasis by resveratrol-mediated inactivation of tumor-evoked regulatory B cells. J. Immunol. 2013, 191, 4141-4151. [CrossRef]

68. Saud, S.M.; Li, W.; Morris, N.L.; Matter, M.S.; Colburn, N.H.; Kim, Y.S.; Young, M.R. Resveratrol prevents tumorigenesis in mouse model of Kras activated sporadic colorectal cancer by suppressing oncogenic Kras expression. Carcinogenesis 2014, 35, 2778-2786. [CrossRef]

69. Li, W.; Ma, X.; Li, N.; Liu, H.; Dong, Q.; Zhang, J.; Yang, C.; Liu, Y.; Liang, Q.; Zhang, S.; et al. Resveratrol inhibits Hexokinases II mediated glycolysis in non-small cell lung cancer via targeting Akt signaling pathway. Exp. Cell Res. 2016, 349, 320-327. [CrossRef]

70. Mikula-Pietrasik, J.; Sosinska, P.; Ksiazek, K. Resveratrol inhibits ovarian cancer cell adhesion to peritoneal mesothelium in vitro by modulating the production of $\alpha 5 \beta 1$ integrins and hyaluronic acid. Gynecol. Oncol. 2014, 134, 624-630. [CrossRef]

71. Zhao, Y.; Yuan, X.; Li, X.; Zhang, Y. Resveratrol significantly inhibits the occurrence and development of cervical cancer by regulating phospholipid scramblase 1. J. Cell. Biochem. 2018, 120, 1527-1531. [CrossRef] [PubMed]

72. Ou, X.; Chen, Y.; Cheng, X.; Zhang, X.; He, Q. Potentiation of resveratrol-induced apoptosis by matrine in human hepatoma HepG2 cells. Oncol. Rep. 2014, 32, 2803-2809. [CrossRef] [PubMed]

73. Yang, Z.; Xie, Q.; Chen, Z.; Ni, H.; Xia, L.; Zhao, Q.; Chen, Z.; Chen, P. Resveratrol suppresses the invasion and migration of human gastric cancer cells via inhibition of MALAT1-mediated epithelial-to-mesenchymal transition. Exp. Ther. Med. 2019, 17, 1569-1578. [CrossRef] [PubMed]

74. Pezzuto, J.M. Resveratrol: Twenty years of growth, development and controversy. Biomol. Ther. 2019, 27, 1-14. [CrossRef] [PubMed]

75. Basly, J.P.; Marre-Fournier, F.; Bail, J.C.L.; Habrioux, G.; Chulia, A.J. Estrogenic/antiestrogenic and scavenging properties of (E)- and (Z)- resveratrol. Life Sci. 2000, 66, 769-777. [CrossRef]

76. Nakagawa, H.; Kiyozuka, Y.; Uemura, Y.; Senzaki, H.; Shikata, N.; Hioki, K.; Tsubura, A. Resveratrol inhibits human breast cancer cell growth and may mitigate the effect of linoleic acid, a potent breast cancer cell stimulator. J. Cancer Res. Clin. Oncol. Suppl. 2001, 127, 258-264. [CrossRef]

77. Folkerd, E.; Dowsett, M. Sex hormones and breast cancer risk and prognosis. Breast 2013, 22, S38-S43. [CrossRef]

78. Yildiz, F. Phytoestrogens in Functional Foods, 1st ed.; CRC Pres: Boca Raton, FL, USA, 2005; pp. 210-211, ISBN 9780429113802.

79. Cai, H.; Scott, E.; Kholghi, A.; Andreadi, C.; Rufini, A.; Karmokar, A.; Britton, R.G.; Horner-Glister, E.; Greaves, P.; Jawad, D.; et al. Cancer chemoprevention: Evidence of a nonlinear dose response for the protective effects of resveratrol in humans and mice. Sci. Transl. Med. 2015, 7, 298ra117. [CrossRef]

80. Ahmad, A.; Ahmad, R. Resveratrol mitigate structural changes and hepatic stellate cell activation in $\mathrm{N}$ '-nitrosodimethylamine-induced liver fibrosis via restraining oxidative damage. Chem. Biol. Interact. 2014, 221, 1-12. [CrossRef]

81. Ahmad, A.; Ahmad, R. Proteomic approach to identify molecular signatures during experimental hepatic fibrosis and resveratrol supplementation. Int. J. Biol. Macromol. 2018, 119, 1218-1227. [CrossRef]

82. Tanriverdi, G.; Kaya-Dagistanli, F.; Ayla, S.; Demirci, S.; Eser, M.; Unal, Z.S.; Cengiz, M.; Oktar, H. Resveratrol can prevent $\mathrm{CCl}_{4}$-induced liver injury by inhibiting Notch signaling pathway. Histol. Histopathol. 2016, 31, 769-784. [PubMed]

83. Xin, P.; Han, H.; Gao, D.; Cui, W.; Yang, X.; Ying, C.; Sun, X.; Hao, L. Alleviative effects of resveratrol on nonalcoholic fatty liver disease are associated with up regulation of hepatic low density lipoprotein receptor and scavenger receptor class B type I gene expressions in rats. Food Chem. Toxicol. 2013, 52, 12-18. [CrossRef] [PubMed]

84. Li, L.; Hai, J.; Li, Z.; Zhang, Y.; Peng, H.; Li, K.; Weng, X. Resveratrol modulates autophagy and NF-кB activity in a murine model for treating non-alcoholic fatty liver disease. Food Chem. Toxicol. 2014, 63, 166-173. [CrossRef] [PubMed] 
85. Ma, Z.; Zhang, Y.; Li, Q.; Xu, M.; Bai, J.; Wu, S. Resveratrol improves alcoholic fatty liver disease by downregulating HIF-1 $\alpha$ expression and mitochondrial ROS production. PLoS ONE 2017, 12, e1834268. [CrossRef]

86. Tang, L.; Yang, F.; Fang, Z.; Hu, C. Resveratrol ameliorates alcoholic fatty liver by inducing autophagy. Am. J. Chin. Med. 2016, 44, 1207-1220. [CrossRef]

87. Hajinejad, M.; Pasbakhsh, P.; Omidi, A.; Mortezaee, K.; Nekoonam, S.; Mahmoudi, R.; Kashani, I.R. Resveratrol pretreatment enhanced homing of SDF-1-preconditioned bone marrow-derived mesenchymal stem cells in a rat model of liver cirrhosis. J. Cell. Biochem. 2018, 119, 2939-2950. [CrossRef]

88. Bai, Y.; An, R. Resveratrol and sildenafil synergistically improve diabetes-associated erectile dysfunction in streptozotocin-induced diabetic rats. Life Sci. 2015, 135, 43-48. [CrossRef]

89. Gencoglu, H.; Tuzcu, M.; Hayirli, A.; Sahin, K. Protective effects of resveratrol against streptozotocin-induced diabetes in rats by modulation of visfatin/sirtuin-1 pathway and glucose transporters. Int. J. Food Sci. Nutr. 2015, 66, 314-320. [CrossRef]

90. Zhao, W.; Li, A.; Feng, X.; Hou, T.; Liu, K.; Liu, B.; Zhang, N. Metformin and resveratrol ameliorate muscle insulin resistance through preventing lipolysis and inflammation in hypoxic adipose tissue. Cell. Signal. 2016, 28, 1401-1411. [CrossRef]

91. Brawerman, G.M.; Kereliuk, S.M.; Brar, N.; Cole, L.K.; Seshadri, N.; Pereira, T.J.; Xiang, B.; Hunt, K.L.; Fonseca, M.A.; Hatch, G.M.; et al. Maternal resveratrol administration protects against gestational diabetes-induced glucose intolerance and islet dysfunction in the rat offspring. J. Physiol. 2019, 597, 4175-4192. [CrossRef]

92. Guo, R.; Liu, B.; Wang, K.; Zhou, S.; Li, W.; Xu, Y. Resveratrol ameliorates diabetic vascular inflammation and macrophage infiltration in $\mathrm{db} / \mathrm{db}$ mice by inhibiting the NF-кB pathway. Diabetes Vasc. Dis. Res. 2014, 11, 92-102. [CrossRef] [PubMed]

93. Li, A.; Zhang, S.; Li, J.; Liu, K.; Huang, F.; Liu, B. Metformin and resveratrol inhibit Drp1-mediated mitochondrial fission and prevent ER stress-associated NLRP3 inflammasome activation in the adipose tissue of diabetic mice. Mol. Cell. Endocrinol. 2016, 434, 36-47. [CrossRef] [PubMed]

94. Qiao, Y.; Gao, K.; Wang, Y.; Wang, X.; Cui, B. Resveratrol ameliorates diabetic nephropathy in rats through negative regulation of the p38 MAPK/TGF-beta1 pathway. Exp. Ther. Med. 2017, 13, 3223-3230. [CrossRef] [PubMed]

95. Nishimura, Y.; Sasagawa, S.; Ariyoshi, M.; Ichikawa, S.; Shimada, Y.; Kawaguchi, K.; Kawase, R.; Yamamoto, R.; Uehara, T.; Yanai, T.; et al. Systems pharmacology of adiposity reveals inhibition of EP300 as a common therapeutic mechanism of caloric restriction and resveratrol for obesity. Front. Pharmcol. 2015, 6, 199. [CrossRef]

96. Wang, B.; Sun, J.; Li, L.; Zheng, J.; Shi, Y.; Le, G. Regulatory effects of resveratrol on glucose metabolism and T-lymphocyte subsets in the development of high-fat diet-induced obesity in C57BL/6 mice. Food Funct. 2014, 5, 1452-1463. [CrossRef]

97. Chang, C.; Lin, K.; Peng, K.; Day, Y.; Hung, L. Resveratrol exerts anti-obesity effects in high-fat diet obese mice and displays differential dosage effects on cytotoxicity, differentiation, and lipolysis in 3T3-L1 cells. Endocr. J. 2016, 63, 169-178. [CrossRef]

98. Parmar, A.; Mula, R.V.R.; Azhar, Y.; Shashidharamurthy, R.; Rayalam, S. Resveratrol increases catecholamine synthesis in macrophages: Implications on obesity. FASEB J. 2016, S1, 301.

99. Zou, T.; Chen, D.; Yang, Q.; Wang, B.; Zhu, M.; Nathanielsz, P.W.; Du, M. Resveratrol supplementation of high-fat diet-fed pregnant mice promotes brown and beige adipocyte development and prevents obesity in male offspring. J. Physiol. London 2017, 595, 1547-1562. [CrossRef]

100. Huang, Y.; Zhu, X.; Chen, K.; Lang, H.; Zhang, Y.; Hou, P.; Ran, L.; Zhou, M.; Zheng, J.; Yi, L.; et al. Resveratrol prevents sarcopenic obesity by reversing mitochondrial dysfunction and oxidative stress via the PKA/LKB1/AMPK pathway. Aging 2019, 11, 2217-2240. [CrossRef]

101. Cheserek, M.J.; Wu, G.; Li, L.; Li, L.; Karangwa, E.; Shi, Y.; Le, G. Cardioprotective effects of lipoic acid, quercetin and resveratrol on oxidative stress related to thyroid hormone alterations in long-term obesity. J. Nutr. Biochem. 2016, 33, 36-44. [CrossRef]

102. Cui, X.; Jing, X.; Wu, X.; Yan, M. Protective effect of resveratrol on spermatozoa function in male infertility induced by excess weight and obesity. Mol. Med. Rep. 2016, 14, 4659-4665. [CrossRef] [PubMed] 
103. Regitz, C.; Fitzenberger, E.; Mahn, F.L.; Dussling, L.M.; Wenzel, U. Resveratrol reduces amyloid-beta $\left(\mathrm{A} \beta_{1-42}\right)$-induced paralysis through targeting proteostasis in an Alzheimer model of Caenorhabditis elegans. Eur. J. Nutr. 2016, 55, 741-747. [CrossRef] [PubMed]

104. Porquet, D.; Grinan-Ferre, C.; Ferrer, I.; Camins, A.; Sanfeliu, C.; Del Valle, J.; Pallas, M. Neuroprotective role of trans-resveratrol in a murine model of familial Alzheimer's Disease. J. Alzheimers Dis. 2014, 42, 1209-1220. [CrossRef] [PubMed]

105. Corpas, R.; Grinan-Ferre, C.; Rodriguez-Farre, E.; Pallas, M.; Sanfeliu, C. Resveratrol induces brain resilience against Alzheimer neurodegeneration through proteostasis enhancement. Mol. Neurobiol. 2019, 56, 1502-1516. [CrossRef]

106. Wang, Z.; Zhang, J.; Duan, Y.; Zhang, Q.; Li, G.; Zheng, D. MicroRNA-214 participates in the neuroprotective effect of resveratrol via inhibiting alpha-synuclein expression in MPTP-induced Parkinson's disease mouse. Biomed. Pharmacother. 2015, 74, 252-256. [CrossRef]

107. Murphy, E. Estrogen signaling and cardiovascular disease. Circ. Res. 2011, 109, 687-696. [CrossRef]

108. Mosca, L.; Barrett-Connor, E.; Wenger, N.K. Sex/gender differences in cardiovascular disease prevention: What a difference a decade makes. Circulation 2011, 124, 2145-2154. [CrossRef]

109. Louis, X.L.; Raj, P.; Chan, L.; Zieroth, S.; Netticadan, T.; Wigle, J.T. Are the cardioprotective effects of the phytoestrogen resveratrol sex-dependent? Can. J. Physiol. Pharmacol. 2019, 97, 503-514. [CrossRef]

110. Soylemez, S.; Gurdal, H.; Sepici, A.; Akar, F. The effect of long-term resveratrol treatment on relaxation to estrogen in aortae from male and female rats: Role of nitric oxide and superoxide. Vascul. Pharmacol. 2008, 49, 97-105. [CrossRef]

111. Di Liberto, V.; Makela, J.; Korhonen, L.; Olivieri, M.; Tselykh, T.; Malkia, A.; Do Thi, H.; Belluardo, N.; Lindholm, D.; Mudo, G. Involvement of estrogen receptors in the resveratrol-mediated increase in dopamine transporter in human dopaminergic neurons and in striatum of female mice. Neuropharmacology 2012, 62, 1011-1018. [CrossRef]

112. Wagnerova, A.; Babickova, J.; Liptak, R.; Vlkova, B.; Celec, P.; Gardlik, R. Sex differences in the effect of resveratrol on DSS-induced colitis in mice. Gastroenterol. Res. Pract. 2017, 2017, 8051870. [CrossRef] [PubMed]

113. Apostolidou, C.; Adamopoulos, K.; Iliadis, S.; Kourtidou-Papadeli, C. Alterations of antioxidant status in asymptomatic hypercholesterolemic individuals after resveratrol intake. Int. J. Food Sci. Nutr. 2016, 67, 541-552. [CrossRef] [PubMed]

114. Mansur, A.P.; Roggerio, A.; Goes, M.F.S.; Avakian, S.D.; Leal, D.P.; Maranhao, R.C.; Strunz, C.M.C. Serum concentrations and gene expression of sirtuin 1 in healthy and slightly overweight subjects after caloric restriction or resveratrol supplementation: A randomized trial. Int. J. Cardiol. 2017, 227, 788-794. [CrossRef] [PubMed]

115. Tome-Carneiro, J.; Gonzalvez, M.; Larrosa, M.; Garcia-Almagro, F.J.; Aviles-Plaza, F.; Parra, S.; Yanez-Gascon, M.J.; Ruiz-Ros, J.A.; Garcia-Conesa, M.T.; Tomas-Barberan, F.A.; et al. Consumption of a grape extract supplement containing resveratrol decreases oxidized LDL and ApoB in patients undergoing primary prevention of cardiovascular disease: A triple-blind, 6-month follow-up, placebo-controlled, randomized trial. Mol. Nutr. Food Res. 2012, 56, 810-821. [CrossRef] [PubMed]

116. Bo, S.; Gambino, R.; Ponzo, V.; Cioffi, I.; Goitre, I.; Evangelista, A.; Ciccone, G.; Cassader, M.; Procopio, M. Effects of resveratrol on bone health in type 2 diabetic patients. A double-blind randomized-controlled trial. Nutr. Diabetes 2018, 8, 51. [CrossRef] [PubMed]

117. Asghari, S.; Asghari-Jafarabadi, M.; Somi, M.; Ghavami, S.; Rafraf, M. Comparison of calorie-restricted diet and resveratrol supplementation on anthropometric indices, metabolic parameters, and serum sirtuin-1 levels in patients with nonalcoholic fatty liver disease: A randomized controlled clinical trial. J. Am. Coll. Nutr. 2018, 37, 223-233. [CrossRef] [PubMed]

118. Turner, R.S.; Thomas, R.G.; Craft, S.; van Dyck, C.H.; Mintzer, J.; Reynolds, B.A.; Brewer, J.B.; Rissman, R.A.; Raman, R.; Aisen, P.S. A randomized, double-blind, placebo-controlled trial of resveratrol for Alzheimer disease. Neurology 2015, 85, 1383-1391. [CrossRef]

119. Kantartzis, K.; Fritsche, L.; Bombrich, M.; Machann, J.; Schick, F.; Staiger, H.; Kunz, I.; Schoop, R.; Lehn-Stefan, A.; Heni, M.; et al. Effects of resveratrol supplementation on liver fat content in overweight and insulin-resistant subjects: A randomized, double-blind, placebo-controlled clinical trial. Diabetes Obes. Metab. 2018, 20, 1793-1797. [CrossRef] 
120. Poulsen, M.M.; Vestergaard, P.F.; Clasen, B.F.; Radko, Y.; Christensen, L.P.; Stodkilde-Jorgensen, H.; Moller, N.; Jessen, N.; Pedersen, S.B.; Jorgensen, J.O.L. High-dose resveratrol supplementation in obese men an investigator-initiated, randomized, placebo-controlled clinical trial of substrate metabolism, insulin sensitivity, and body composition. Diabetes 2013, 62, 1186-1195. [CrossRef]

121. Thazhath, S.S.; Wu, T.; Bound, M.J.; Checklin, H.L.; Standfield, S.; Jones, K.L.; Horowitz, M.; Rayner, C.K. Administration of resveratrol for $5 \mathrm{wk}$ has no effect on glucagon-like peptide 1 secretion, gastric emptying, or glycemic control in type 2 diabetes: A randomized controlled trial. Am. J. Clin. Nutr. 2016, 103, 66-70. [CrossRef]

122. Van der Made, S.M.; Plat, J.; Mensink, R.P. Trans.-resveratrol supplementation and endothelial function during the fasting and postprandial phase: A randomized placebo-controlled trial in overweight and slightly obese participants. Nutrients 2017, 9, 5966.

123. McDermott, M.M.; Leeuwenburgh, C.; Guralnik, J.M.; Tian, L.; Sufit, R.; Zhao, L.; Criqui, M.H.; Kibbe, M.R.; Stein, J.H.; Lloyd-Jones, D.; et al. Effect of resveratrol on walking performance in older people with peripheral artery disease The RESTORE randomized clinical trial. JAMA Cardiol. 2017, 2, 902-907. [CrossRef] [PubMed]

124. Zhu, W.; Qin, W.; Zhang, K.; Rottinghaus, G.E.; Chen, Y.; Kliethermes, B.; Sauter, E.R. Trans.-resveratrol alters mammary promoter hypermethylation in women at increased risk for breast cancer. Nutr. Cancer 2012, 64, 393-400. [CrossRef] [PubMed]

(C) 2020 by the authors. Licensee MDPI, Basel, Switzerland. This article is an open access article distributed under the terms and conditions of the Creative Commons Attribution (CC BY) license (http://creativecommons.org/licenses/by/4.0/). 